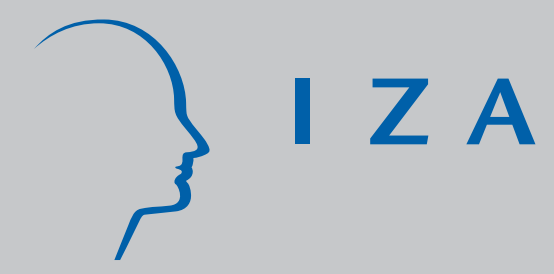

IZA DP No. 4061

International Terrorism, Political Instability and the Escalation Effect

Nauro F. Campos

Martin Gassebner

March 2009 


\title{
International Terrorism, Political Instability and the Escalation Effect
}

\author{
Nauro F. Campos \\ Brunel University, \\ CEPR, KOF and IZA
}

\section{Martin Gassebner}

ETH Zurich and KOF

\section{Discussion Paper No. 4061 \\ March 2009}

\author{
IZA \\ P.O. Box 7240 \\ 53072 Bonn \\ Germany \\ Phone: +49-228-3894-0 \\ Fax: +49-228-3894-180 \\ E-mail: iza@iza.org
}

\begin{abstract}
Any opinions expressed here are those of the author(s) and not those of IZA. Research published in this series may include views on policy, but the institute itself takes no institutional policy positions.

The Institute for the Study of Labor (IZA) in Bonn is a local and virtual international research center and a place of communication between science, politics and business. IZA is an independent nonprofit organization supported by Deutsche Post Foundation. The center is associated with the University of Bonn and offers a stimulating research environment through its international network, workshops and conferences, data service, project support, research visits and doctoral program. IZA engages in (i) original and internationally competitive research in all fields of labor economics, (ii) development of policy concepts, and (iii) dissemination of research results and concepts to the interested public.
\end{abstract}

IZA Discussion Papers often represent preliminary work and are circulated to encourage discussion. Citation of such a paper should account for its provisional character. A revised version may be available directly from the author. 


\section{ABSTRACT \\ International Terrorism, Political Instability and the Escalation Effect ${ }^{*}$}

What are the main causes of international terrorism? The lessons from the surge of academic research that followed 9/11 remain elusive. The careful investigation of the relative roles of economic and political conditions did little to change the fact that existing econometric estimates diverge in size, sign and significance. In this paper we present a new rationale (the escalation effect) stressing domestic political instability as the main reason for international terrorism. Econometric evidence from a panel of more than 130 countries (yearly from 1968 to 2003) shows this to be a much more promising avenue for future research than the available alternatives.

JEL Classification: C25, D72, F59, H56, P48

Keywords: terrorism, international terrorism, political instability, escalation

Corresponding author:

Nauro F. Campos

Department of Economics and Finance

Brunel University

Uxbridge UB8 3PH

United Kingdom

E-mail:nauro.campos@brunel.ac.uk

\footnotetext{
* We would like to thank Brock Blomberg, Fabrizio Coricelli, Martha Crenshaw, Jakob de Haan, Benjamin Jones, Simon Luechinger, Thierry Mayer, Maria Petrova, James Robinson, Colin Rowat, Friedrich Schneider, Mathias Thoenig and seminar participants at the 17th Silvaplana Workshop in Political Economy and CEPR Workshop on Conflict and Globalisation (Paris) for valuable comments on earlier versions. All remaining errors are entirely our own.
} 


\section{Introduction}

The best political weapon is the weapon of terror. Cruelty commands respect. Men may hate us. But, we don't ask for their love; only for their fear.

\section{Himmler}

To be feared is to fear: no one has been able to strike terror into others and at the same time enjoy peace of mind.

\section{Seneca}

Terrorism is defined as premeditated political violence against civilians with the objective of maximizing media exposure to the act and, ultimately, to the terror group and/or to its "cause."1 Because it targets non-military personnel (that is, because the focus of terrorist activities are "civilians" or "non-combatants"), terrorist acts fundamentally differ from civil wars, guerrilla warfare and riots. Because the aim is to raise the profile of the "cause," one main objective of terrorism is to maximize media exposure so as to further the atmosphere of fear. As the relative importance of exposure vis-à-vis the terror act itself increases (the propaganda eclipsing the deed), the technical and planning aspects become relatively more important.

Although the events of 9/11 generated a surge of academic research on the causes of terrorism, the main lessons from this research remain elusive. There is no doubt we learned a lot in recent years about the aggregate behaviour of terrorism over time, about its economic and political costs and about its microeconomic motives, but considerable disagreement remains

\footnotetext{
${ }^{1}$ The definition we use in this paper is from Krueger and Maleckova (2003, p. 120): "terrorism means premeditated, politically motivated violence perpetrated against noncombatant targets by subnational groups or clandestine agents, usually intended to influence an audience. The term 'international terrorism' means terrorism involving citizens or the territory of more than one country."
} 
about its root causes. ${ }^{2}$ This literature has produced a careful and detailed investigation of the relative roles of economic conditions (GDP levels and rates, poverty, income inequality), political rights and democracy (examining linear and non-linear effects) and interstate violent conflicts, among other lesser factors. However, the empirical estimates diverge harshly in size, statistical significance and even sign. More importantly, this literature has by and large downplayed the role of domestic political instability. Is domestic political instability a root cause of international terrorism? Here we introduce the escalation effect arguing that it is indeed a main cause of international terrorism.

There are three aspects of our paper that we think constitute important differences vis-àvis previous studies. One is that domestic instability is explicitly considered as one main reason for international terrorism. The second is that we use different types of political instability (to identify the escalation effect), as well as different indicators of international terrorism (that reflect the number of terror acts as well as their severity). And a third difference refers to the policy implications, which diverge from current policy prescriptions in general and, in particular, from the dominant (especially among non-economists) "failed states" perspective.

One self-imposed restriction we must explain up-front is that we focus solely on international terrorism (that is, we exclude domestic terrorism from our analysis). International terrorism is defined as terrorist acts involving citizens and/or territory of more than one country. One main reason for this focus is that it "stacks the cards" against the escalation effect. We claim that domestic political instability drives international terrorism. Naturally, if these spillover effects are substantial, they will be larger on domestic than on international terrorism. One reason for this is that civil wars and guerrilla warfare may (although not necessarily do) involve acts of

\footnotetext{
${ }^{2}$ The thorough literature review by Llussá and Tavares (2008) finds that "comprehensive studies that address the long-run determinants of terrorism are scarce." We summarize this body of literature in Table 1 below and discuss it in Section 2.
} 
domestic terrorism. If this is correct, the effects we estimate for, say civil wars, risk being substantially larger for domestic than for international terrorism. ${ }^{3}$ Hence, focusing on international terrorism provides conservative estimates of the roles of different forms of domestic political instability.

What are the stylized facts of international terrorism? Figures 1 to 5 show our data, across regions and from 1968 to 2004, in two important dimensions: the total number of terrorist events and their total number of fatalities. The main stylized fact is that although there have been on average a decreasing number of terror attacks per year, the average number of deaths they have caused has systematically increased over the last 40 years or so. ${ }^{4}$ Moreover, there are important regional differences: e.g., lethality increased across all regions since at least 2000, except SubSaharan Africa. In terms of the total numbers, our data shows that most attacks took place in the Middle East and Europe, while the most lethal attacks were in Africa, Asia and the Middle East.

Using data on various aspects of international terrorism (namely, total number of terror acts, total fatalities, and median fatalities) covering more than 130 countries, yearly from 1968 until $2003,{ }^{5}$ our main findings are that (1) civil wars and guerrilla warfare are robustly associated with various aspects of international terrorism, while riots and strikes are not, and this association is even stronger for fatalities than for the number of attacks, (2) the explanatory power of escalation does not seem to decrease over time, (3) per capita GDP, population size and foreign aid are found not to be consistently important in explaining international terrorism, and (4)

\footnotetext{
${ }^{3}$ Unsurprisingly, we find that the effect of the domestic political instability variables is substantially larger when accounting for both domestic and international terrorism. This is despite international terrorist events being a fraction of the total number of terrorist attacks. For example, "for the year 2003, the MIPT Terrorism Knowledge Base reports 1,536 events of domestic terrorism, but only 240 events of international terrorism" (Abadie, 2006). Another reason is that the data series for domestic terrorism starts much later (for instance, in our data set it starts only in 1998) which would further constrain the analysis.

${ }^{4}$ This is unaffected by the exclusion of the 9/11 attacks, one of the most lethal attacks in history.

${ }^{5}$ The Freedom House democracy indices start in 1972. Using Polity IV measures instead (which contains data from 1968 onwards) does not affect our results.
} 
proximity to the U.S. matters (measured as the share of votes cast in the United Nations General Assembly that are in line with the U.S. vote).

What are the mechanisms through which the escalation effect may operate? Although the difficulties in disentangling such mechanisms are well-known, we conjecture that the main mechanism at work has to do with learning-by-doing and the accumulation of terrorist human capital. Terror requires schooling and sophisticated training. Politically unstable countries offer propitious conditions. It has been correctly noted that terrorist groups operate human resources policies which favour better educated or economically better-off individuals (Krueger and Maleckova, 2003). A related aspect that has received less attention is that the human capital required for terrorism is specific and involves a complex mix of skills which are costly to acquire and maintain. ${ }^{6}$ Terrorist skills have a high rate of obsolescence and are not easily transferable across occupations. Moreover, certain forms of domestic political instability (say, guerrilla warfare and civil war) provide for the honing of military, tactical, and organizational skills needed to carry out terrorist acts, while other forms (such as riots, anti-government demonstrations and strikes) should not provide for the same level or types of skills.

The paper is organized as follows. In Section 2 we elaborate on the escalation effect and contrast it with other available explanations. Section 3 presents the econometric methodology and the data we use. Section 4 discusses our econometric estimates and the various robustness tests to which they were subjected. Section 5 concludes.

\footnotetext{
${ }^{6}$ Training may turn out to be the major component of the costs of a terrorist operation: "Very cheap terrorist attacks can create significant anxiety - the material cost of a suicide attack may be as little as $\$ 150$ and on average kills twelve people" (Sandler et al., 2008, p. 3).
} 


\section{The Escalation Effect as an Alternative Explanation}

In this section, we answer the following questions: what are the main reasons that have been identified for international terrorism across countries and over time? And what are the strengths and weaknesses of these different explanations?

The body of evidence we are most concerned with is the set of quantitative studies whose objective is to identify the main or deep causes of international terrorism across large samples of countries and over time. ${ }^{7}$ Such studies have a common aim which is to uncover broad regularities as their ultimate goal is to offer evidence-backed policy recommendations. More specifically, the body of evidence we focus on are those 27 papers summarized in Table 1 . This table includes most (but surely not all) existing econometric work on the causes of international terrorism.

What does this evidence show? First, it is much smaller than one might have expected, inter alia for the $9 / 11$ events. Second, the cross-country coverage is extensive, ranging from 71 to 193 countries (thus most studies pool developing and developed countries). Third, there are still quite a large number of papers that only report cross-sectional estimates which may be worrisome because, as we can see from Figures 1 to 5, there have been fluctuations in international terrorism and choosing a point in time, or a short period, to examine the causes of terror will likely produce biased results. Fourth, a large number of studies (12 out of 27) report negative binomial estimates, which is the appropriate econometric methodology for the issues at hand. Fifth, and finally, the source of the data used in the majority of studies is ITERATE or MIPT (Enders 2007), with most using the number of terror attacks as the main terrorism indicator and about half focusing on target as opposed to origin countries. Notice that here we use the total number of international terrorist attacks, but we go beyond this by also reporting estimates based on their

\footnotetext{
${ }^{7}$ Although a comprehensive review of the economic literature on terrorism, including measurement issues, causes, consequences and economic costs is beyond the scope of this paper (as our focus is on its causes), it can be found in Enders (2007), Frey et al. (2007), and Llussá and Tavares (2008).
} 
severity (measured as the number of fatalities). Further, we also use the target and not the origin definition because their measurement is less error-prone. Such errors arise from trying to establish the nationality of the terrorists/groups involved, so it is not surprising to find that the data availability for terror acts according to origin is considerably worse than that according to target (indeed, in the MIPT dataset only for one-third of all terrorist acts the perpetrators are known). Moreover, the nationality often says little about who funded, planned and organized the attack. In light of the escalation effect, this choice also generates more conservative estimates. An attack involving various nationalities, like $9 / 11$, is counted as one event in the target country while it is counted as one event for each terrorist in each of the origin countries inflating the global number of events.

What can we learn from these studies? What are the main causes of international terrorism according to this body of empirical evidence? The literature highlights various reasons for terror: democracy, poverty, size, and conflict. We discuss each of these in turn.

One first deep cause of international terrorism according to the empirical literature is democracy. The intuition is that societies lacking democratic liberties constrain political protest into clandestine and often violent forms, among them terrorism. There are a few important qualifications to this story, such as the notion of a non-linear relationship between political rights and terror, that political rights seem more closely associated with terrorism than civil liberties, and the finding that freedom of press does not seem to play as major a role as other political considerations. As noted, existing estimates diverge in size, significance and sign so discrepancies with respect to the role of democracy are not the exception, but the rule. For instance, while Abadie (2006) finds that political rights are a crucial factor, Tavares (2004) argues otherwise.

A second reason for international terrorism highlighted by the empirical literature is 
poverty (low levels of per capita GDP). This has been a very contentious issue. Different studies have examined different aspects such as levels of per capita GDP, growth rates, and the role of recessions (Gini coefficients, the Human Development Index, as well as various measures of government expenditures on health and education and foreign aid inflows have also been used.) Again, there are papers showing per capita GDP or growth rates of GDP to be important determinants of international terrorism (e.g., Blomberg et al., 2004), and papers reporting that these are not important determinants (e.g., Krueger and Maleckova, 2003). Burgoon (2006) and Azam and Thelen (2008) show that government expenditures (on health and education) and foreign aid, respectively, tend to reduce the incidence of terrorist attacks.

A third commonly investigated reason is country size, often measured as total population and/or as percentage of the total population living in urban areas. The justification is that larger fractions of population in urban centres make terror attacks more deadly, all else equal. Table 1 show that most papers incorporate population and find that it is an important determinant of terrorist events, with few papers finding that it is not relevant.

One last important reason for international terrorism found in the empirical literature is conflict. Various studies examine the role of interstate conflicts, wars, and regime durability on the occurrence of international terrorism. Some find that whether a country has participated in a war matters, others find that it is not important vis-à-vis international terrorism (e.g., Lai, 2007, and Burgoon, 2006, respectively).

Because our focus is on the role of violent domestic conflict, we discuss in detail the only three studies we find (out of 27) which use domestic political instability as a correlate of international terrorism. These are Li (2005), Lai (2007) and Krueger and Laitin (2008). Li (2005) shows that less durable regimes tend to attract more international terrorism. Yet, not only is there no justification for this inclusion (other than "the variable is too important to exclude," Li, 2005, 
p. 286) but the coefficient on regime durability is neither mentioned nor discussed anywhere in the paper. Lai (2007) presents results for the role of civil wars in explaining terrorism, but the justification and interpretation of the domestic instability effect differ. Lai (2007) justifies the use of civil wars as an explanatory variable as a proxy of "state failure." ${ }^{8}$ The hypothesis is that the "number of terrorist incidents originating from a state is likely to be higher as the operating costs within that state decrease" (Lai, 2007, p. 300), with five variables used to proxy for those costs (including civil war, inter-state wars and telephone lines). Krueger and Laitin (2008) also use domestic political instability variables to explain international terrorism. They find that "fast growing, stable countries are more likely to be the origin and target of suicide attacks," where political stability is a dummy variable capturing whether or not the country is stable (from the World Bank's Governance Matters dataset). There are two important differences vis-à-vis our hypothesis: one is that this finding is restricted to suicide bombings, and the second is that it implies that instability actually reduces terrorism.

This brief review of the literature lead us to conclude (a) that the low levels of political development and the low levels of economic development seem to be the two main reasons studied in the empirical literature, and (b) that this literature has by and large ignored the importance of the escalation process and the attendant role of domestic political instability for the propagation of international terrorism.

One explanation that combines political and economic development reasons, namely the "failed states hypothesis," seems now dominant in policy and political science circles (although not, as the review above makes clear, in the economics discussion). The idea is simple: weak

\footnotetext{
8 "Governments involved in a civil war are not likely to have the resources available to effectively control their territory, allowing groups to organize without fear of government reprisals... In addition to a civil war, states involved in an interstate war are also likely to have less ability to control their own borders. Similar to the effects of involvement in a civil war, interstate conflict can potentially create a situation where a government's resources are unavailable to address internal problems" (Lai, 2007, p. 302).
} 
states produce international terrorists. As synthesized in the opening sentence of the Brookings Institution's Annual Report on Weak States: “Since September 11, 2001, the United States and other governments have frequently asserted that threats to international peace and security often come from the world's weakest states" (Rice and Patrick, 2008, p.3).

But what exactly are weak or failed states? The Brookings index is a composite of 20 indicators (5 in each of four "baskets": economic, political, security and social welfare). Under security one finds incidence of coups, territory affected by conflict, political stability, human rights abuses and conflict intensity. ${ }^{9}$ Thus, countries in which there is domestic or international terrorism are more likely (everything else the same) to be classified as weak states. ${ }^{10}$

The shortcomings we see in the "failed states view as a major cause of international terrorism" should now be clear. The failed states hypothesis is basically unfalsifiable: failed states produce terrorism because they are weak states and their weakness shows in their inability to contain terrorism. From a different and more policy-oriented perspective, this hypothesis lacks predictive power: we can not identify well which states are weak before a terror attack occurs because states will be classified as weak inter alia by the occurrence of terror. ${ }^{11}$ Further, the "failed states view" does not resolve the debate (by combining economic and political development concerns), it simply delays it by making it harder to disentangle their relative roles. Finally, it is unsurprising that empirically a composite index that includes the occurrence of terrorism does a good job in explaining terrorism across countries and over time.

In this paper we introduce the escalation effect. It basically posits that domestic political

\footnotetext{
9 See Rice and Patrick (2008) for a detailed discussion of each of these components and "baskets." They also provide an excellent review of various other indexes of state failure. We should note that our contention is exclusively with state failure as a cause of international terrorism as we view state failure as a very useful concept in other contexts.

${ }^{10}$ See also Foreign Policy's Failed States Index (Foreign Policy, 2008).

${ }^{11}$ Both the mechanisms through which political instability can economically "weaken" a state and whether or not this weakening actually takes place are still unclear (Campos and Nugent, 2002).
} 
instability is a deep cause of international terrorism, across countries and over time. Our argument is that domestic political instability has a first-order effect on the production of terrorist attacks, while the various alternative explanations (mainly, low levels of political and economic development) offered in the literature do not exhibit such first-order effects. More specifically, we formulate this hypothesis as follows:

(1) domestic political instability is a main or deep cause of international terrorism because terrorism requires skills (mostly military and organizational) that can be honed in countries that are politically unstable or have experienced political instability;

(2) terror skills are easily acquired under severe political instability (for example, in guerrilla warfare, civil wars and armed revolutions conditions), but are not easily acquired under other forms of domestic political instability (such as riots, antigovernment demonstrations and general strikes);

(3) the escalation effect is independent from state-sponsored terrorism so that the end of the Cold War allow us to assess its significance in that we should expect that the importance of domestic political does not decrease over time and, in particular, does not decrease after 1989 (see O'Kane, 2007 on state-sponsored terrorism); and

(4) if such skills do indeed accumulate across countries and over time one shall expect that the severity of terror attacks (which is usually proxied by the number of resulting casualties) will increase over time even if the numbers of attacks do not.

Because our objective is to present the escalation effect as a worthwhile alternative explanation, we have to show that it holds across countries and over time (i.e., that it does not lack generality). Consequently, we must use macro data at the country-level on the terrorist attacks as well as on the various alternative explanations that have been offered. Yet, we are 
aware that the mechanism we favour (based on skills acquisition and the importance of training) can not be fully identified using this type of data. We present two main arguments in defence of this mechanism, one based on anecdotal evidence and the other on our identification strategy.

The first argument is based on the large body of more anecdotal evidence on the importance of training for international terrorism. Smith (2008) reviews a number of case studies and concludes that the "cases of McVeigh, the Sept. 11 hijackers and Rudolph are actually unusual. In fact, we found that most terrorists live close to their selected targets, and they engage in a great deal of preparation - some over the course of months or even years - that has the potential of coming to the attention of local law enforcement... Comparing the 10 international terrorist incidents that occurred on American soil, we found that the average planning cycle for international terrorists was 92 days, as opposed to 14 days for environmental terrorists." (Smith, 2008, p. 3-5). Chivers and Rohde (2002) provide a detailed discussion of what and how terrorist training involves based on training manuals from various terrorists groups across the globe. They report on the vast array of skills embodied in what they call the "core curriculum," skills such as casing and targeting, planning and finances, codes and secure communication, map reading, celestial and advanced land navigation, demolition techniques, first aid, internal security, combat techniques, manufacturing of bombs and improvised explosive devices, use of firearms and weapons (such as Kalashnikov and M16 rifles, PK machine guns, 82-milimiter mortars, shoulderfired rockets and portable anti-aircraft missiles), assassination techniques as well as escape and evasion tactics (the latter including methods for resisting interrogation). It is also worth mentioning that Chivers and Rohde (2002) interviewed various military instructors whom expressed surprise not only with the depth and range of the skills being taught, but even more so with how the curriculum has been carefully put together, in independent modules or packages.

The second argument we present for favouring the skills mechanism rests on our layered 
identification strategy. We argue that guerrilla warfare and civil wars (and, to a lesser extent, riots) are forms of domestic instability which provide the skills - military, tactical, and organizational - required to carry out international terrorist acts across the globe. Equally importantly, we also hypothesize that demonstrations and strikes play much smaller roles because they are non-violent forms of domestic instability and, therefore, do not support the acquisition of the key skills necessary for international terrorism attacks. A second layer we provide is that we also argue that the importance of the escalation effect has increased over time and this is despite the fact that state sponsored terrorism has become much less prevalent since the end of the Cold War, thereby curtailing foreign-supported training opportunities and related terror skills acquisition activities, and by the same token expanding the equivalent domestically-supported opportunities and activities.

\section{Econometric Method and Data}

The objective of this section is to present the dataset we put together to assess the empirical relevance of the escalation effect and discuss the econometric tools we chose to carry out this assessment. We test whether the escalation effect has empirical support using a unique panel data set with more than 130 countries, yearly since 1968. Our preferred estimates are those from maximum likelihood negative binomial regressions.

As dependent variables we use three different measures of international terrorism: the (absolute) number of attacks, the number of fatalities caused by these attacks and the number of fatalities caused by the attack of median intensity. All three measures are obtained for each country-year pair. The data source for our terror indicators is the MIPT Terrorism Knowledge 
Base. $^{12}$ Each country-year combination without entry, that is, in which no terrorist event is recorded, is assigned a zero.

The resulting count variables show a distribution which is strongly skewed. Moreover all three indicators exhibit significant over-dispersion, i.e., the variance is larger than the mean (see Table 2 for sources and summary statistics of all variables in our analysis). Over-dispersion makes the use of standard estimation methods problematic. More specifically, to take into account this feature of the data we use maximum-likelihood negative binomial regressions. In order to address the panel structure of our data, we use the conditional fixed effects negative binomial model. Let the expected value and the variance be given by:

$$
\begin{aligned}
& E\left(y_{i t}\right)=e^{\left(\alpha_{i}+\beta^{\prime} X_{i t}\right)}=\lambda_{i t} \\
& \operatorname{Var}\left(y_{i t}\right)=\lambda_{i t}\left(1+\delta_{i}\right),
\end{aligned}
$$

where $y_{i t}$ is the count of the respective terror measure (total attacks, total fatalities, and median fatalities) in country $\mathrm{i}$ and year $\mathrm{t}, \alpha_{i}$ are the country specific effects and $X_{i t}$ is the vector of explanatory variables. The dispersion (i.e., variance divided by the mean) is given by $\left(1+\delta_{i}\right)$ and is constant over time for each country. Following Hausman et al. (1984), if the joint probability is conditioned on the observed sum of counts for each country (i.e., conditional on all $y_{i}=\sum_{t=1}^{T_{i}} y_{i t}$ ) then the conditional log likelihood function takes the following form: ${ }^{13}$

\footnotetext{
${ }^{12}$ See Sandler and Enders (2007) for a thorough discussion of the measurement of terrorism activity, in general, and Memorial Institute for the Prevention of Terrorism (MPIT) data in particular.

${ }^{13}$ For a discussion of the fixed effects negative binomial model, see also Cameron and Trivedi (1998) and Guimarães (2008).
} 


$$
\begin{aligned}
\ln L= & \sum_{i=1}^{n}\left[\ln \Gamma\left(\sum_{t=1}^{T_{i}} e^{\left(\beta^{\prime} X_{i t}\right)}\right)+\ln \Gamma\left(\sum_{t=1}^{T_{i}} y_{i t}+1\right)-\ln \Gamma\left(\sum_{t=1}^{T_{i}} e^{\left(\beta^{\prime} X_{i t}\right)}+\sum_{t=1}^{T_{i}} y_{i t}\right)\right. \\
& \left.+\sum_{t=1}^{T_{i}}\left\{\ln \Gamma\left(e^{\left(\beta^{\prime} X_{i t}\right)}+y_{i t}\right)-\ln \Gamma\left(e^{\left(\beta^{\prime} X_{i t}\right)}\right)-\ln \Gamma\left(y_{i t}+1\right)\right\}\right],
\end{aligned}
$$

where $\Gamma$ is the gamma distribution. Notice that $\alpha_{i}$ drops out by conditioning on the sum of the counts of the dependent variable. Consequently, all countries without any observed terrorism over the whole sample period are dropped from the estimation. ${ }^{14}$ The coefficients can be obtained by standard maximization of the log likelihood.

While our dependent variable is available for all country-year observations, this is not true for some of our explanatory variables. Thus our panel dataset is unbalanced and the number of observations also depends on the choice of explanatory variables. In order to minimize potential endogeneity problems, we lag all relevant explanatory variables by one year. To account for common shocks, we include yearly time dummies in all specifications.

Our key variables are the various measures of domestic political instability and political violence that reflect the escalation effect. These include a dummy variable for the occurrence of civil war and a count variable for instances of guerrilla warfare. The source for the former is Gleditsch et al. (2002) and for the latter Databanks International (2005). Civil war takes on the value of one for years in which at least 1,000 deaths occur in battles between the government's armed forces and opposition groups (without foreign intervention). Guerrilla warfare reflects the number of cases in which violence is used against the government by civilians aiming at the overthrow of the current regime.

\footnotetext{
${ }^{14}$ This causes changes in the maximum number of countries we use for different dependent variables. Yet we have also estimated our regressions using the random effects negative binomial estimator (which does not drop the countries with zero terror events). The results are quantitatively the same and available upon request. Also notice that the number of countries dropped is relatively small.
} 
Other indicators of domestic political instability we use are the number of riots, strikes and demonstrations (all from Databanks International, 2005). Demonstrations are peaceful gatherings of at least 100 people voicing their disagreement with government policies, while riots are demonstrations which involve the use of force and violence. Finally, the definition of general strikes require the involvement of a minimum of 1000 industrial workers of more than one employer and are aimed at national policies and/or authorities. Additionally, we include regime duration which is measured as the number of years that the current political regime is in place. This data is available from Marshall and Jaggers (2002).

As noted, the empirical literature on the causes of terrorism has highlighted the importance of the political system. One well-established result is that of a non-linear relationship between political rights and terrorism. However, the interpretation of the magnitude and significance of squared terms in non-linear estimations such as the negative binomial is not straightforward (see, e.g., Ai and Norton, 2003). Thus, we model the potential non-linearity by including the lagged level of political freedom and its change in the regressions instead (as in Dreher and Gassebner, 2008). Political freedom is the average of the two indicators "political rights" and "civil liberties" provided by Freedom House (2005). ${ }^{15}$

Economic conditions have also received a great deal of attention in the empirical literature on the causes of terrorism. In all specifications we thus use real GDP per capita while we also include economic growth to test the robustness of our results (both measures are taken from World Bank, 2006). We address the hypothesis that the size of the country might determine how often terrorists strike by including population size, also taken from World Bank (2006).

\footnotetext{
${ }^{15}$ Conceptually, these are different phenomena, but empirically their simple pair-wise correlation is high (0.98 in our data). Although we only report results for political freedom, we have also re-estimated all our models below using only political rights and only civil liberties and find that this does not affect our conclusions. These are available from the authors' upon request.
} 
We employ five more control variables to assess the sensitiveness of our baseline results. The first is political proximity to the United States. Dreher and Gassebner (2008) show that being close to the U.S. triggers additional and more severe terror attacks. Proximity is measured from voting in the UN General Assembly and is taken from Voeten (2004). Thacker (1999) suggests that votes in line with the U.S. are coded 1, abstentions/absences are coded 0.5 and votes in opposition to the U.S. are coded 0 . We obtain the proximity measure by dividing the resulting sums by the total number of votes for each country in each year. Hence, the variable ranges from zero to one, with one showing total agreement with the U.S. and zero, total disagreement.

As can be seen from the plots of our terrorism measures (Figures 1 to 5), the occurrence of terror varies across regions. We take this into account by using the conditional fixed effects negative binomial estimator and also by including an OECD membership dummy in our regressions (data taken from the OECD webpage).

From the discussion on the role of poverty and terrorism comes the notion that foreign aid might also be an important determinant of terror. However, the sign of the relationship is not straightforward. If poverty is a source of terrorism then (poverty-reducing) aid might be one way to counter terrorism. However, Krueger and Maleckova (2003) and Krueger and Laitin (2008) present evidence that terrorists are recruited from the middle classes. Azam and Delacroix, (2006) point out that aid could end up breeding additional terror attacks if it increases the ranks of the middle class. ${ }^{16}$ Our aid data are from the World Bank (2006) and includes both official development assistance (ODA) and official aid (measured as a share of GNI).

The characteristics of potential target countries for terrorism play an important role thus we also include the urbanization rate. It might be more fruitful from a terrorist's point of view to

16 "Some use this as an argument against aid, which should be cut because it would increase the probability of terrorist attacks, by increasing the supply of better off and educated people" (Azam and Delacroix, 2006, p.330). 
strike in urban areas. On the one hand, the population density and transportation infrastructure may increase the effectiveness of an attack. On the other hand, an attack in a large city benefits from more media coverage and thus the attention that the terror group receives. Hence, we include the share of urban population in our empirical setup (data are from World Bank, 2006).

As our final control variable we introduce trade openness, measured as imports plus exports divided by GDP (from World Bank, 2006). As a proxy for globalization, the role of openness is a priori ambiguous. On the one hand, strong ties to the world economy might provide incentives for national governments to engage in counter-terrorism activity as not to jeopardize its role in the world economy. On the other hand, increased exposure to foreign products, values and ideas might trigger hatred which could be channelled into terrorist activity.

\section{Empirical Results}

The first column of Table 3 shows a parsimonious model, columns 2 to 7 each adds one additional control variable and the final column shows the full model, including all variables simultaneously. ${ }^{17}$ The coefficients in all tables below represent incidence-rate ratios. As such, a one unit change in the corresponding variable represents an expected change in the terror variable of (coefficient minus 1) times 100 percent. Hence all values above 1 indicate a terror increasing relationship while the reverse holds for values below 1 .

Table 3 shows our results for the absolute number of transnational terror events as the dependent variable. Overall, we find strong support for the escalation effect. Civil wars, guerilla warfare and riots all exhibit the expected positive relationship and are all statistically highly significant. All else equal, our model predicts that going from a situation of no civil war to a

\footnotetext{
${ }^{17}$ Notice that the reported coefficients show how a change of $x$ in $t$ results in a change of $y$ in $t+1$, as we lagged all but one of our regressors as indicated in the tables.
} 
situation of civil war would result in an increase in terror attacks by approximately 30 percent (e.g., for column 1: $(1.3042-1) \times 100=30.42$ percent). The magnitude of the effect of guerilla attacks is almost identical: all else equal, increasing the number of guerilla incidences by 1 results in roughly 30 percent more (international) terror events. The effect of riots is considerably smaller. One additional riot results in an increase of terror events by approximately 3.5 percent, an increase by one standard deviation (1.7) therefore causes a 6 percent increase in terror events. Moreover, we show that lesser forms of political violence, strikes and demonstrations, do not seem to help explaining the occurrence of international terrorism which is in line with our hypothesis. To put the magnitude of our results in perspective consider the number of events our model predicts. If we set the country fixed effects to zero, the predicted number of terror events range between 0.17 and 37.69 for the country-year observations. The average predicted number of international terror events for the estimation sample of column 1 is 0.95 as compared to the observed sample average of 2.18 .

Regarding our main control variables, most of our findings are in line with the previous literature. We find that per capita GDP is statistically insignificant in all specifications. More populous countries indeed seem to suffer more attacks. According to our fuller specification in column 8 , one standard deviation increase in population size results in 44 percent additional terror events. Surprisingly, we find only limited support for a non-linear relationship between political freedoms and terror. While the level and the change variables have opposing signs, the latter is often statistically insignificant. Moreover, the overall effect seems to be of lesser economic importance with the maximum being an increase of 12 percent in events for an increase of one point in political freedoms. For the full specification of column 8 both coefficients are insignificant. We have also estimated models without the rate of change and find that this does not affect our main results. Political stability, measured as the number of years the current regime 
is in place, seems to have a dampening effect on terror. The effect of additional one year of regime life is pretty small (especially when compared to say civil wars) and even an increase by one standard deviation (30 years) reduces attacks by just 24 percent.

Turning to our additional covariates, there seems to be strong evidence on the roles of political proximity to the U.S., OECD membership and the urbanization rate. All of these three variables have the expected effects: changing the voting behavior from completely against the U.S. to completely in line would lead to more than a doubling of terror attacks. OECD countries experience on average 48 percent more attacks, while an increase of the urbanization rate by one standard deviation would result in a 23 percent increase. The growth rate of per capita GDP, foreign aid and economic openness do not exhibit a statistically significant relationship to terror attacks according to our results.

Table 4 delves deeper into these issues by investigating whether regional differences are important. We find important differences in terms of which forms of domestic political instability play major roles in explaining the number of international terror acts across the different regions. Specifically, we find that in Asia civil war and riots are the main determinants of international terrorism acts, in the Americas that role is played by guerrilla warfare instead, for Africa it is played by riots, and for the Middle East we find it is a combination of civil wars and guerrilla warfare. ${ }^{18}$ In the case of Europe, although we find that none of the violent forms of domestic political instability are related to the occurrence of terror acts, we uncover strong evidence that the duration of the political regime (a well-known measure of political instability) is negatively related to the occurrence of terrorist acts. Also note that these results maintain the differentials among the effects from the various political instability variables we find above. In particular, the

\footnotetext{
${ }^{18}$ Notice that at times the negative binomial estimator converges only by dropping some of the explanatory variables from the estimation (for instance, for the Africa and Middle East regressions above the dummy for OECD is dropped.)
} 
effects of riots tend to be considerably smaller than those from civil wars and guerrilla warfare. Although one additional riot generates 10 percent more international terrorist acts in Asia and 25 percent more in Africa, these pale in comparison to the effects of the other variables (for instance, we estimate that civil war occurrence in Asia increase the number of terror acts by slightly more than 80 percent.)

Columns 6 to 9 in Table 4 present similar specifications but now splitting the sample according to level of per capita GDP (based on the World Bank classification into high, uppermiddle, lower-middle and low income groups from Easterly and Sewadeh, 2001). Here again we uncover some interesting differences. Starting with the high income countries, we find that domestic political instability in terms of shorter regime duration and the occurrence of antigovernment demonstrations both are associated with an (relatively small but statistically significant) increase in the number of international terror events. On the other hand, we find that civil war and riots are consistently important predictors of the number of terror acts in the lower, lower-middle and upper-middle per capita income groups, with the larger effects observed for the upper-middle income countries (the occurrence of civil war increases the number of terror acts in upper-middle income countries by almost 90 percent while riots generates a similar increase of 12 percent.) We estimate that the effects of guerrilla warfare tend to be significant only for the middle-income countries. These effects are also large with, for instance, the occurrence of guerrilla warfare in a lower-middle income country generating an almost 60 percent increase in the number of international terrorism events. Finally, with respect to general strikes, we find that they tend to increase the number of terror acts for lower-middle income countries (one additional strike generating about 14 percent more international terror events) but seems to have the opposite effect for upper-middle income countries (in light of the results above suggesting that 
the Asian countries may be playing a large role in this effect). ${ }^{19}$

Table 5 furthers this analysis by focusing on fatalities caused by international terrorism, instead of the absolute number of terror attacks (that is, we look at the severity of terror rather than just its occurrence). With respect to our key variables, the overall pattern is similar to the one obtained before. Both the occurrence of civil war and guerilla warfare robustly increases the number of international terror casualties. Indeed, the magnitude of these two effects is higher than for the occurrence of terror: the number of terror fatalities increases by roughly 50 percent due to the presence of civil war and more than 60 percent for one (additional) act of guerrilla warfare. $^{20}$

Of the other political instability variables, riots are only significant for the most complete specification in column 8 and only at the $10 \%$ level. The estimated effect has almost the same magnitude as before. Demonstrations, on the other hand, seem to matter more (significant in 6 out of the 8 regressions) but are not significant in our complete specification. As before, strikes seem to be seldom important vis-à-vis international terrorism activity.

As for our other covariates, most our previous findings prevail. Thus, the determinants of terrorism as such (the intensive margin) also seem to matter in determining its severity. There are a few exceptions worth noting. It seems that richer countries suffer from more fatal attacks (despite not facing more terror overall): In 6 out of the 8 regressions GDP per capita is positive

\footnotetext{
${ }^{19} \mathrm{We}$ have also split the sample along the lines of the extent of political freedom, using the three categories proposed by Freedom House, namely free, partly-free and not free. Interestingly, we find that the effects of civil wars and general strikes are much larger in the countries classified as not free, while the effects of guerrilla warfare are more important in the partly-free countries. We believe future research would benefit from studying in details the effects of a wider number of features of democratic regimes.

${ }^{20}$ If we include civil war or guerrilla warfare as the only escalation variable, the respective coefficient increases both in size and significance (indeed, up to a doubling of the civil war coefficient). Results are available upon request. We have also experimented with a principal component index and the results are equally supportive of the escalation effect, with the resulting coefficient also being larger in magnitude than the single coefficients.
} 
and significant. Yet, further examination reveals that this effect seems driven by urbanization as in those specifications where the urbanization rate is included this per capita GDP effect vanishes. Moreover, in our complete specification in column 8 , the effect is terror dampening and significant at the $5 \%$ level. Thus richer countries suffer fewer fatalities, but more urbanized countries do suffer more casualties. The corresponding changes in fatalities due to one standard deviation are -32 percent (GDP per capita) and 68 percent (urbanization). Moreover, the magnitude of the proximity to the U.S. effect is much larger for terror fatalities: completely moving towards the U.S. form an initial situation of complete objection would increase the number of victims by a factor of $10 .{ }^{21}$ All other results are comparable in magnitude with our previous findings.

We also use the number of casualties at the attack of median intensity as our dependent variable in Table 6 as this helps to minimize the effects of outliers. The findings do not change with respect to guerilla warfare, which continues to be highly statistically significant and of similar magnitude as above. However, while the magnitude of the civil war variable also seems unchanged, it becomes marginally insignificant ( $\mathrm{p}$-value of 0.105 ) in our full specification (column 8), and statistically significant only in 5 out of 8 specifications. Otherwise, we obtain very similar findings, except that the role of political freedom declines even further but the change becomes marginally significant for the full specification, providing support to the notion that political liberalization may decrease fatalities at the median event. The role of regime stability and political proximity seems to be much larger and the finding that urbanization rather than per capita GDP matters also received further confirmation.

We subjected the results above to a wide array of tests of robustness. As the main

\footnotetext{
${ }^{21}$ While this effect might seem enormous, it is important to keep in mind that maximum and minimum of the variable are 0.06 and 0.84 while the standard deviation is 0.14 .
} 
conclusion from these is that they do not change our findings, the estimates are not presented for the sake of space but are available upon request. First, given the attention paid to the potential role of democracy in driving terror, we test whether our results are affected if we use different measures of political freedom. As an alternative to the Freedom House indicators we employ the Polity IV score from Marshall and Jaggers (2002). This leaves all our findings unchanged. Second, we check whether our results are driven by the $9 / 11$ event and its aftermath by rerunning our estimations until only the year 2000. Notice that splitting the sample in this manner also addresses the issue of the potential role of anti-terror measures (as such expenditures and policies have increased and spread substantially following 9/11). This also has no effects whatsoever on our findings. Third, we tested whether or not the importance of the escalation effect has increased since 1968. We find it did as the interaction terms between a time trend and either civil wars or guerrilla warfare turns out always to be positive and significant. ${ }^{22}$ Yet, Ai and Norton (2003) show that the interpretation of interaction terms is quite cumbersome in non-linear estimation models. Therefore, we run rolling regressions. As an example we show the results for the coefficient on guerrilla warfare when regressed on the number of terror fatalities. Our rolling windows are 15 years wide and move forward by one year for each regression. Thus the first regression covers the years 1973-1987 and final regression the years 1989-2003. In total this procedure yields 16 regressions. As the results presented in Figure 6 show, there is a stable yet clear upward trend in the relationship between guerrilla warfare and terrorism suggesting indeed that the importance of this explanation has not decreased over time. ${ }^{23}$ Fourth, we test whether our results simply pick up regional rather than domestic instability. To do so we add annual regional averages of our two central variables, civil war and guerrilla warfare, to the regressions. To avoid

\footnotetext{
${ }^{22}$ This may not be entirely unexpected in light of the fact that state sponsored terrorism has rescinded since the end of the Cold War.

${ }^{23}$ Figure 6 only serves as an example with other setups yielding comparable results.
} 
double counting, we always exclude the country in question. The results show that this does not affect our findings while the regional averages themselves are mostly insignificant.

In order to further investigate whether our results are affected by outliers, we construct a dummy variable which takes on the value 1 for positive outcomes of each of our terror indicators. We then run conditional fixed effects logit regressions (see Chamberlain, 1980), that is, we examine the probability of experiencing terrorism. We find the escalation effect also holds strong in such a less rich empirical setup.

One final objection that could be raised is that our results might suffer from reverse causality. To address this concern we employ maximum likelihood instrumental variables probit estimations with standard errors clustered at the country level. Again, our dependent variables are dummy variables as described above. To instrument our escalation variables we use the variables ethnic tension and religious tension taken from the International Country Risk Guide. These variables measure the degree of tensions within a country which is attributable to racial, nationality or language divisions and religious divisions, respectively. While our findings regarding the escalation effect do not change, the Wald test for exogeneity shows that our central variables are not endogenous to terror. ${ }^{24}$

\section{Conclusions}

Using data on various aspects of international terrorist events (total number of terror events, event occurrence, total fatalities and fatalities at the median event) covering more than 130 countries, yearly from 1968 onwards, our main findings are that (i) civil wars and guerrilla warfare are robustly associated with international terror, while riots and strikes are not, and this association is

\footnotetext{
${ }^{24}$ The null hypothesis of the Wald test is that the regressors are exogenous. We always fail to reject it, e.g., for Civil War the p-values are 0.23 and 0.10 (for terrorism events and fatalities, respectively), while they are 0.49 and 0.20 for guerrilla warfare.
} 
stronger for fatalities than for the number of attacks (that is, we find strong support for the escalation effect), (ii) the explanatory power of escalation seems to increase over time, (iii) somewhat in line with previous research, per capita GDP and foreign aid are not robust factors in explaining international terrorism, and (iv) there is evidence that OECD membership (or being a rich country) is a less important factor than ideological proximity to the U.S.

On the basis of these results, we argue for the importance of the escalation effect in understanding international terrorism and suggest for future research more efforts to uncover the main mechanisms through which it operates. Our main conjecture is that domestic instability escalates into international terrorism because it provides and perfects the skills (military, strategic and organizational) required to carry out international terrorist acts. One example may help underscore the importance of this potential mechanism. In July 2005, the London public transport system suffered two terrorist attacks. The first, in July 7, unfortunately succeeded but the other, two weeks later (July 21), failed. There are many differences between the two events but an examination of the biographies of the two teams of perpetrators reveals one important distinction: the members of the first group seem to have received substantially more training and have received it much closer in time to the attack than those in the second group (Krueger, 2007, p.48).

In terms of the policy lessons our analysis offer, it follows from our findings that one crucial goal of anti-terrorism policy must be the containment of violent conflict around the globe (Collier et al., 2008). However, recent experience suggests that direct military intervention can be counter-productive, ${ }^{25}$ while foreign aid might be effective in the medium- to long-term. ${ }^{26}$ Moreover, from the conflict literature we learn that factors such as inequality, political rights, ethnic polarization and religious fractionalization are not good predictors of civil wars and hence

\footnotetext{
${ }^{25}$ See Axelrod and Borzutzky (2006).

${ }^{26}$ See also Frey and Luechinger (2003) for a discussion on alternatives to deterrence as a way to fight terrorism.
} 
can not be counted on to counter transnational terrorism (Collier and Hoeffler, 2004). However, one of the main factors identified as causing conflict is the availability of finance. Collier and Hoeffler (2004) find that income from commodity exports is one of the main determinants of conflict. In this light, a medium to long-term policy implication would be to diversify the economy so that there is less dependence on commodities. Moreover, the close monitoring of world wide financing operations might be an important way to counter terrorism. Another, unrelated, policy suggestion we offer is for further investments in technology (Crenshaw, 2006; Cragin et al., 2007). Investment is needed to close the gap between what is technologically feasible and the effective disruption and containment of the activities of terrorist groups worldwide. In this light, we take inspiration from the defining effects of Ronald Reagan 1983's "Strategic Defense Initiative" (the "Star Wars" program) on subsequent Cold War events and recommend a similar containment tool: frontier technological investment that aim at yielding innovations that facilitate international coordination and are able to radically minimize the probability of further and more sophisticated transnational terror attacks. 


\section{References}

Abadie, A. (2006), "Poverty, Political Freedom, and the Roots of Terrorism," American Economic Review, 96(2): 50-56.

Ai, C. and E.C. Norton (2003), "Interaction Terms in Logit and Probit Models," Economics Letters 80(1): 123-129.

Axelrod, R. and S. Borzutzky (2006), "NATO and the War on Terror: The Organizational Challenges of the Post 9/11 World," Review of International Organizations 1(3): 293-307.

Azam, J.-P. and A. Delacroix (2006), "Aid and the Delegated Fight against Terrorism,” Review of Development Economics, 10(2): 330-344.

Azam, J.-P. and V. Thelen (2008), "The Roles of Foreign Aid and Education in the War on Terror," Public Choice 135(3-4): 375-397.

Basuchoudhary, A. and W.F. Shughart (2007), "On Ethnic Conflict and the Origins of Terrorism," University of Mississippi, mimeo.

Berman, E. and D.D. Laitin (2008), "Religion, Terrorism and Public Goods: Testing the Club Model,” NBER Working Paper 13725.

Blomberg, B. and G.D. Hess (2008a), "From (No) Butter to Guns? Understanding the Economic Role in Transnational Terrorism," in P. Keefer and N. Loyaza (eds), Terrorism, Economic Development, and Political Openness, Cambridge University Press, 83-115.

Blomberg, B. and G.D. Hess (2008b), "The Lexus and the Olive Branch: Globalization, Democratization, and Terrorism," in P. Keefer and N. Loyaza (eds), Terrorism, Economic Development, and Political Openness, Cambridge University Press, 116-147.

Blomberg, B., Hess, G.D. and A. Weerapana (2004), "Economic Conditions and Terrorism," European Journal of Political Economy 20(2): 463-478.

Blomberg, B. and B.P. Rosendorff (2006), "A Gravity Model of Globalization, Democracy and Transnational Terrorism," University of Southern California Legal Studies Working Paper 12.

Bravo, A. and C. Dias (2006), "An Empirical Analysis of Terrorism: Deprivation, Islamism and Geopolitical Factors," Defence and Peace Economics, 17(4): 329-341.

Burgoon, B. (2006), "On Welfare and Terror: Social Welfare Policies and Political Economic Roots of Terrorism.” Journal of Conflict Resolution, 50(2): 176-203.

Cameron, A.C. and P.K. Trivedi (1998), Regression Analysis of Count Data, New York: Cambridge University Press. 
Campos, N. and J.B. Nugent (2002), "Who is Afraid of Political Instability?" Journal of Development Economics, 67(1): 157-172.

Chamberlain, G. (1980), "Analysis of Covariance with Qualitative Data," Review of Economic Studies 47(1): 225-238.

Chivers, C. and D. Rohde (2002), "Turning Out Guerrillas and Terrorists to Wage a Holy War," The New York Times, March 18, 2002.

Collier, P., L. Chauvet and H. Hegre (2008), "The Security Challenge in Conflict-Prone Countries," Copenhagen Consensus Challenge Paper No. 8.

Collier, P. and A. Hoeffler (2004), "Greed and Grievance in Civil War," Oxford Economic Papers 56(4): 563-595.

Cragin, K., Chalk, P., Daly, S. and B. Jackson (2007), Sharing the Dragon's Teeth: Terrorist Groups and the Exchange of New Technologies, Santa Monica: RAND.

Crenshaw, M. (2006), "Innovation: Decision Points in the Trajectory of Terrorism," Wesleyan University, mimeo.

Databanks International (2005), Cross-National Time-Series Data Archive, 1815-2003, Binghamton, NY.

Dreher, A. and J. Fischer (2008), "Decentralization as a Disincentive for Transnational Terror? An Empirical Test," ETH Zurich, KOF Working Papers 185.

Dreher, A. and M. Gassebner (2008), "Does Political Proximity to the U.S. Cause Terror?" Economics Letters 99(1): 27-29.

Easterly, W. and M. Sewadeh (2001), Global Development Network Growth Database, The World Bank. Economic and Development Research Group.

Enders, W. (2007), "Terrorism: An Empirical Analysis," in T. Sandler and K. Hartley (eds) Handbook of Defense Economics (Volume 2), Amsterdam: Elsevier, 815-866.

Eubank, W. and L. Weinberg (2001), "Terrorism and Democracy: Perpetrators and Victims," Terrorism and Political Violence, 13(1): 155-164

Feldman, N.E. and B.J. Ruffle (2008), "Religious Terrorism: A Cross-Country Analysis," BenGurion University, mimeo.

Foreign Policy (2008), “The Failed States Index,” Foreign Policy Issue 167, July/August 2008.

Freedom House (2005), Freedom in the World, Annual Report, Washington D.C.: Freedom House. 
Frey, B.S. and S. Luechinger (2003), "How to Fight Terrorism: Alternatives to Deterrence," Defence and Peace Economics 14(4): 237-249.

Frey, B.S., Luechinger, S. and A. Stutzer (2007), "Calculating Tragedy: Assessing the Costs of Terrorism," Journal of Economic Surveys 21(1): 1-24.

Freytag, A., Krüger, J.J. and F. Schneider (2006), "The Origins of Terrorism: Cross-Country Estimates with Discrete Choice and Count Data Methods," Linz University, mimeo.

Gleditsch, N., Wallensteen, P., Eriksson, M., Sollenberg, M. and H. Strand (2002), "Armed Conflict 1946-2001: A New Dataset," Journal of Peace Research 39(5): 615-637.

Goldstein, K. (2005), "Unemployment, Inequality and Terrorism: Another Look at the Relationship between Economics and Terrorism," Undergraduate Economic Review, v1.

Guimarães, P. (2008), "The Fixed Effects Negative Binomial Model Revisited," Economics Letters 99(1): 63-66.

Hausman, J., Hall, B. and Z. Griliches (1984), "Economic Models for Count Data with an Application to the Patents-R\&D Relationship," Econometrica 52(4): 909-938.

Krueger, A.B. (2007) What Makes a Terrorist: Economics and the Roots of Terrorism, Princeton: Princeton University Press.

Krueger, A.B. and J. Maleckova (2003), "Education, Poverty and Terrorism: Is there a Casual Connection?" Journal of Economic Perspectives, 17(4): 119-144.

Krueger, A.B. and D.D. Laitin (2008), "Kto Kogo? A Cross-country Study of the Origins and Targets of Terrorism," in P. Keefer and N. Loyaza (eds), Terrorism, Economic Development, and Political Openness, Cambridge, Cambridge University Press, 148-173.

Kurrild-Klitgaard, P., Justesen, M.K. and R. Klemmensen (2006), "The Political Economy of Freedom, Democracy and Transnational Terrorism," Public Choice 128(1-2): 289-315.

Lai, B. (2007), "'Draining the Swamp': An Empirical Examination of the Production of International Terrorism, 1968-1998”, Conflict Management and Peace Science, 24(4): 297-310.

Li, Q. (2005), “Does Democracy Promote or Reduce Transnational Terrorist Incidents?” Journal of Conflict Resolution 49(2): 278-297.

Li, Q. and D. Schaub (2004), "Economic globalization and transnational terrorist incidents: A pooled time series analysis," Journal of Conflict Resolution 48(2): 230-258.

Llussá, F. and J. Tavares (2008), "Economics and Terrorism: What We Know, What We Should Know, and the Data We Need," in P. Keefer and N. Loyaza (eds), Terrorism, Economic Development, and Political Openness, Cambridge University Press, 233-254. 
Marshall, M.G. and K. Jaggers (2002), Polity IV Project: Political Regime Characteristics and Transitions, 1800-2000; http://www.cidcm.umd.edu/inscr/polity/.

O’Kane, R. (2007), Terrorism, London: Pearson Longman.

Piazza, J.A. (2006), "Rooted in Poverty? Terrorism, Poor Economic Development, and Social Cleavages," Terrorism and Political Violence 18(1): 159-177.

Rice, S. and P. Stewart (2008), Index of State Weakness in the Developing World, Washington DC: The Brookings Institution.

Sambanis, N, (2008), "Terrorism and Civil War," in P. Keefer and N. Loyaza (eds), Terrorism, Economic Development, and Political Openness, Cambridge University Press, 174-208.

Sandler, T. and W. Enders (2007), "Applying Analytical Methods to Study Terrorism," International Studies Perspectives 8(3): 287-302.

Sandler, T., Arce, D. and W. Enders (2008), "Transnational Terrorism," Copenhagen Consensus Challenge Paper No. 6.

Smith, B. (2008), “A Look at Terrorist Behavior: How They Prepare, Where They Strike," NIJ Journal (National Institute of Justice, US Department of Justice), Issue No 260, July.

Tavares, J. (2004), “The Open Society Assesses its Enemies: Shocks, Disasters and Terrorist Attacks," Journal of Monetary Economics, 51(5): 1039-1070.

Thacker, S.C. (1999), “The High Politics of IMF Lending,” World Politics 52(1): 38-75.

Voeten, E. (2004), "Documenting Votes in the UN General Assembly," George Washington University. http://home.gwu.edu/ voeten/UNVoting.htm.

Weinberg, L. and W. Eubank (1998), "Terrorism and Democracy: What Recent Events Disclose," Terrorism and Political Violence, 10(1): 108-118.

World Bank (2006), World Development Indicators, CD-ROM, Washington D.C.: World Bank. 
Figure 1.

Average Number (per Country) of International Terrorist Events and Fatalities in Asia

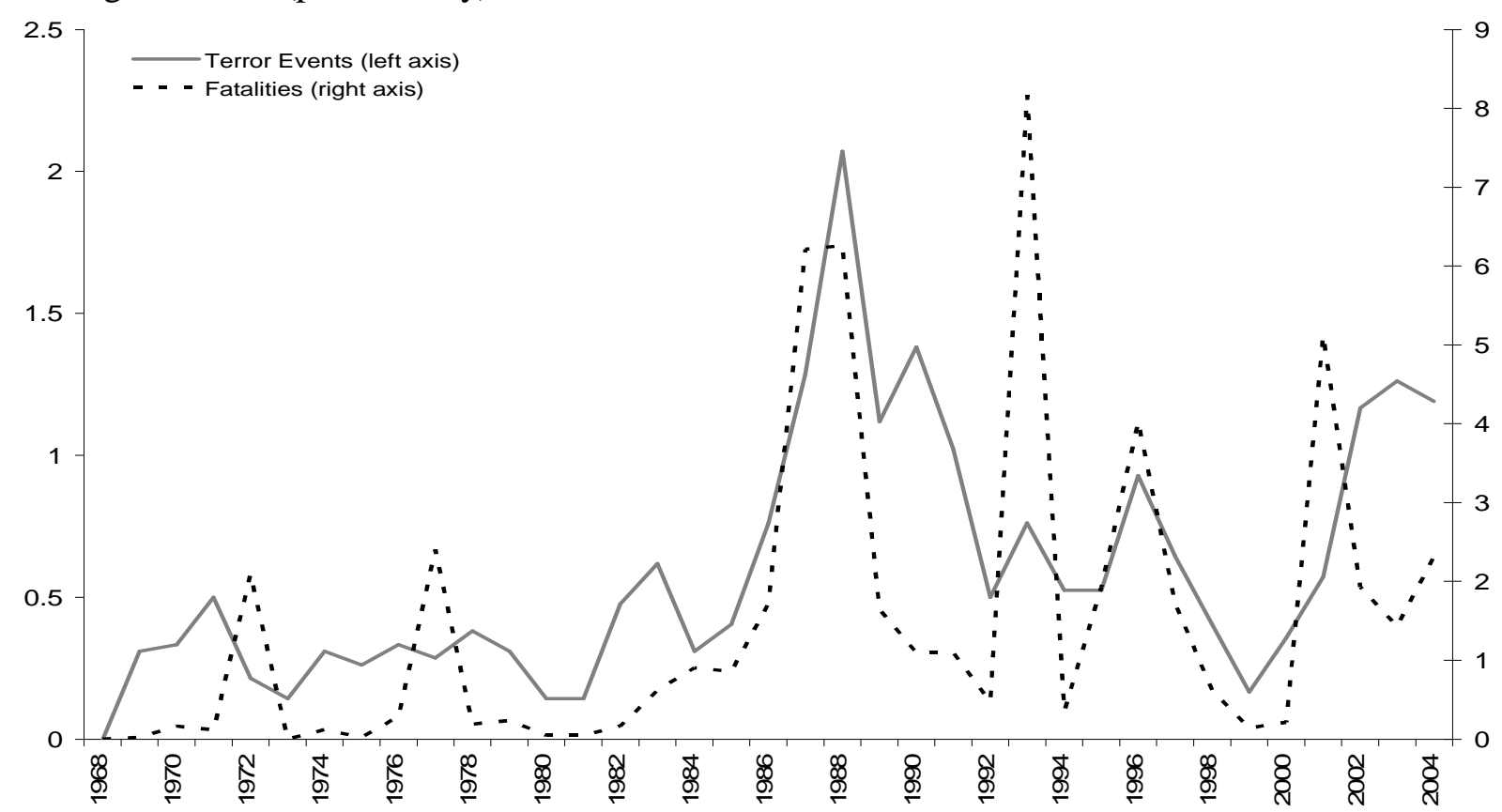

Figure 2.

Average Number (per Country) of International Terrorist Events and Fatalities in the Middle East and North Africa

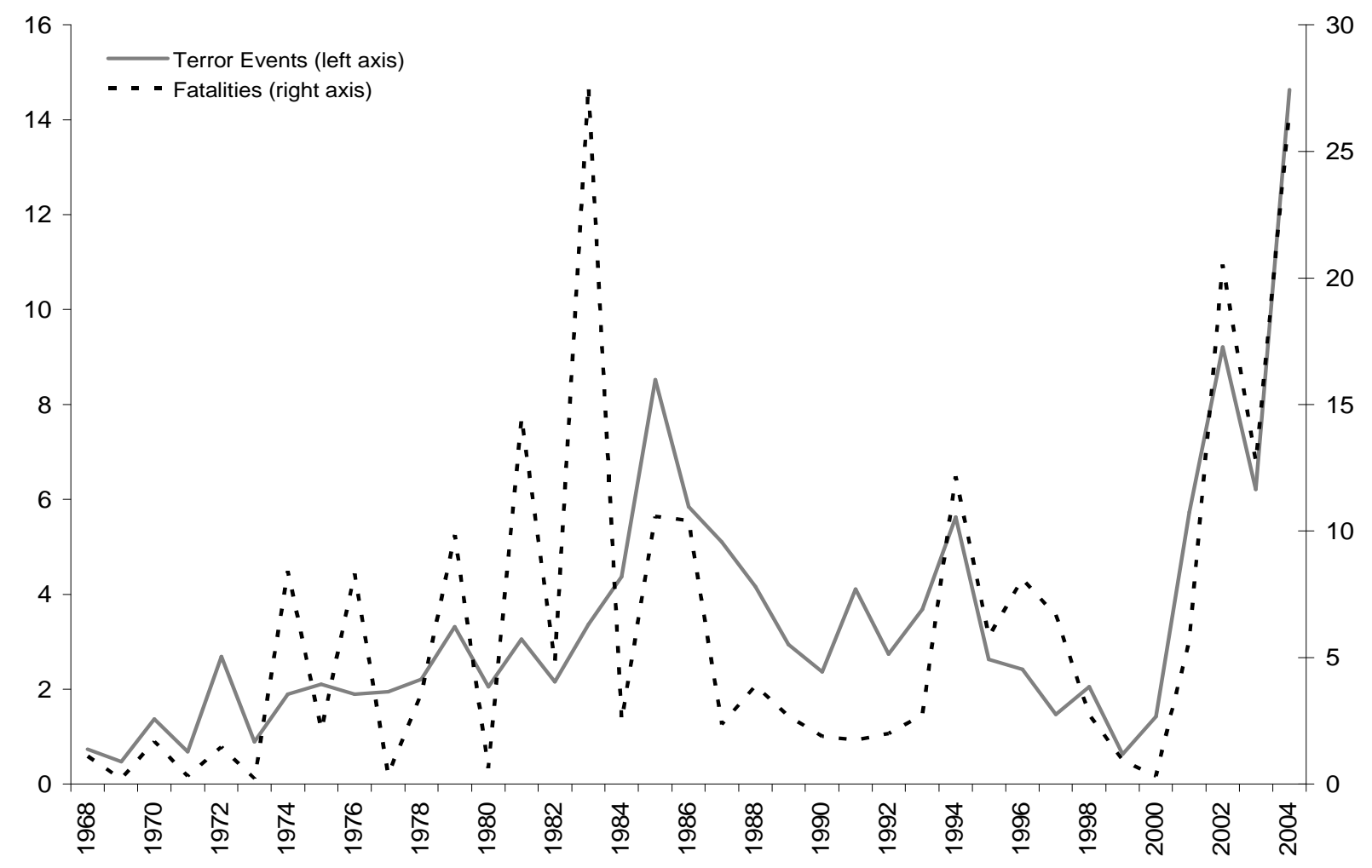


Figure 3.

Average Number (per Country) of International Terrorist Events and Fatalities in the Americas

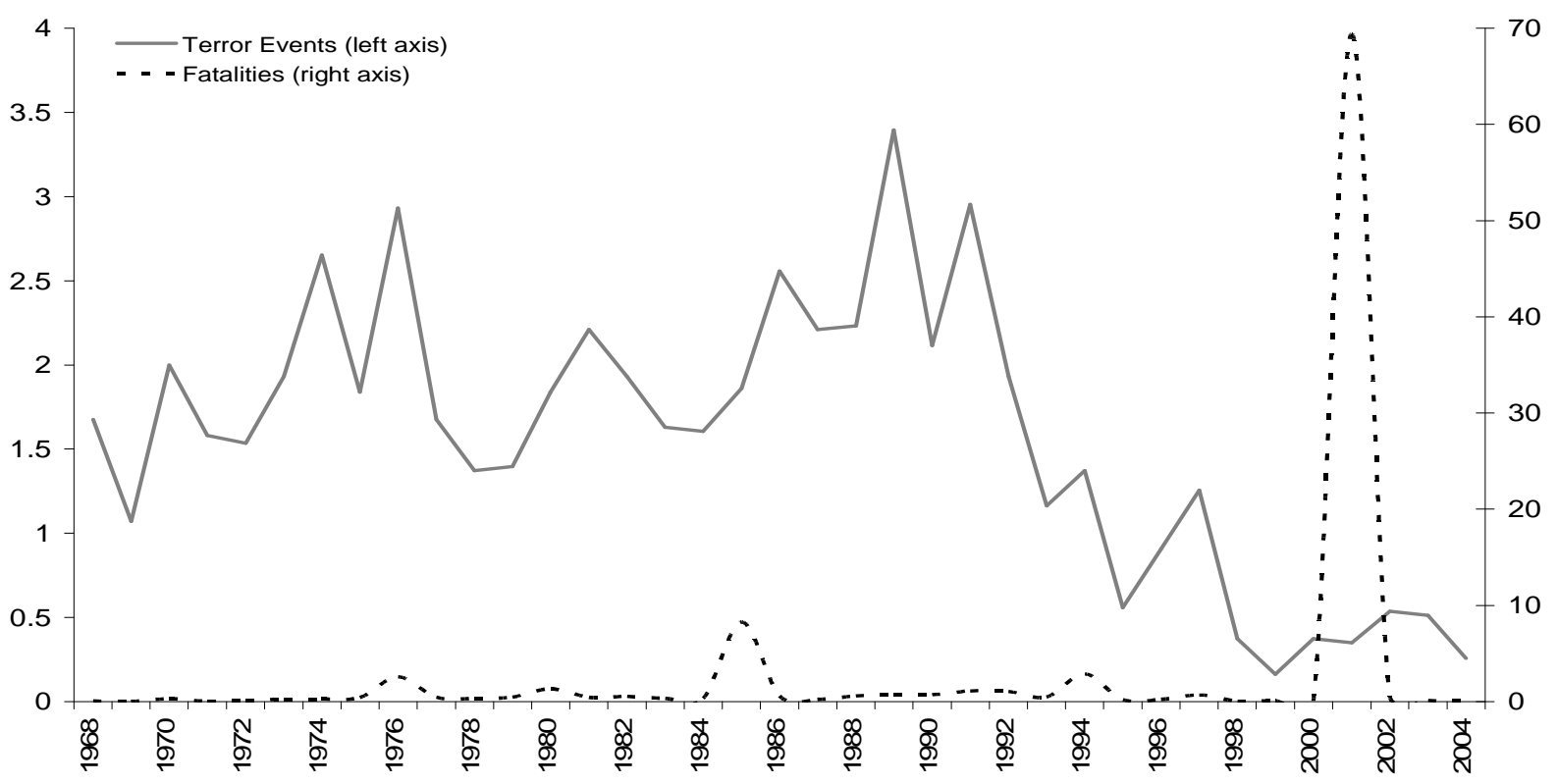

Figure 4.

Average Number (per Country) of International Terrorist Events and Fatalities in Europe

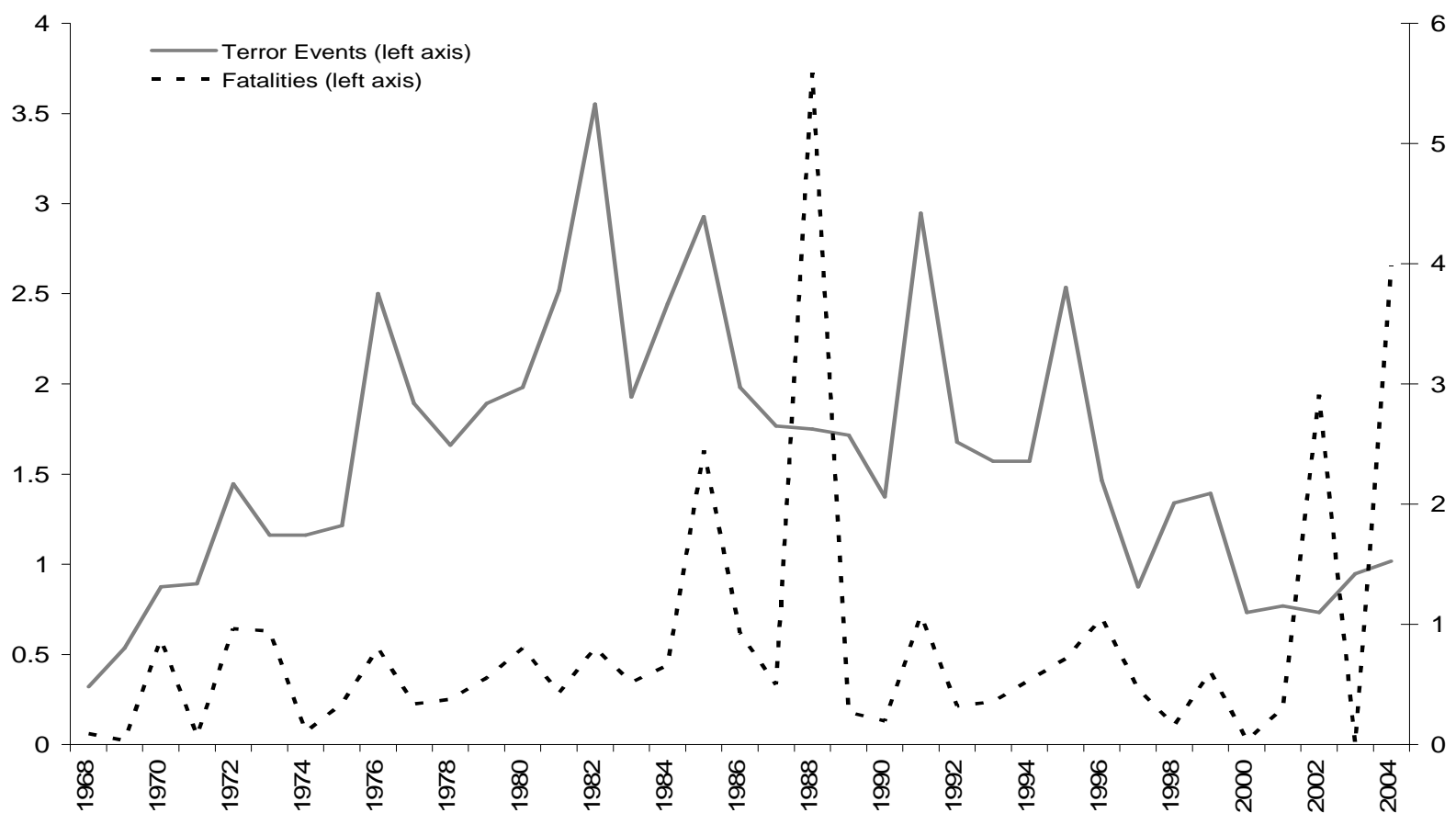


Figure 5.

Average Number (per Country) of International Terrorist Events and Fatalities in Sub-Saharan

Africa

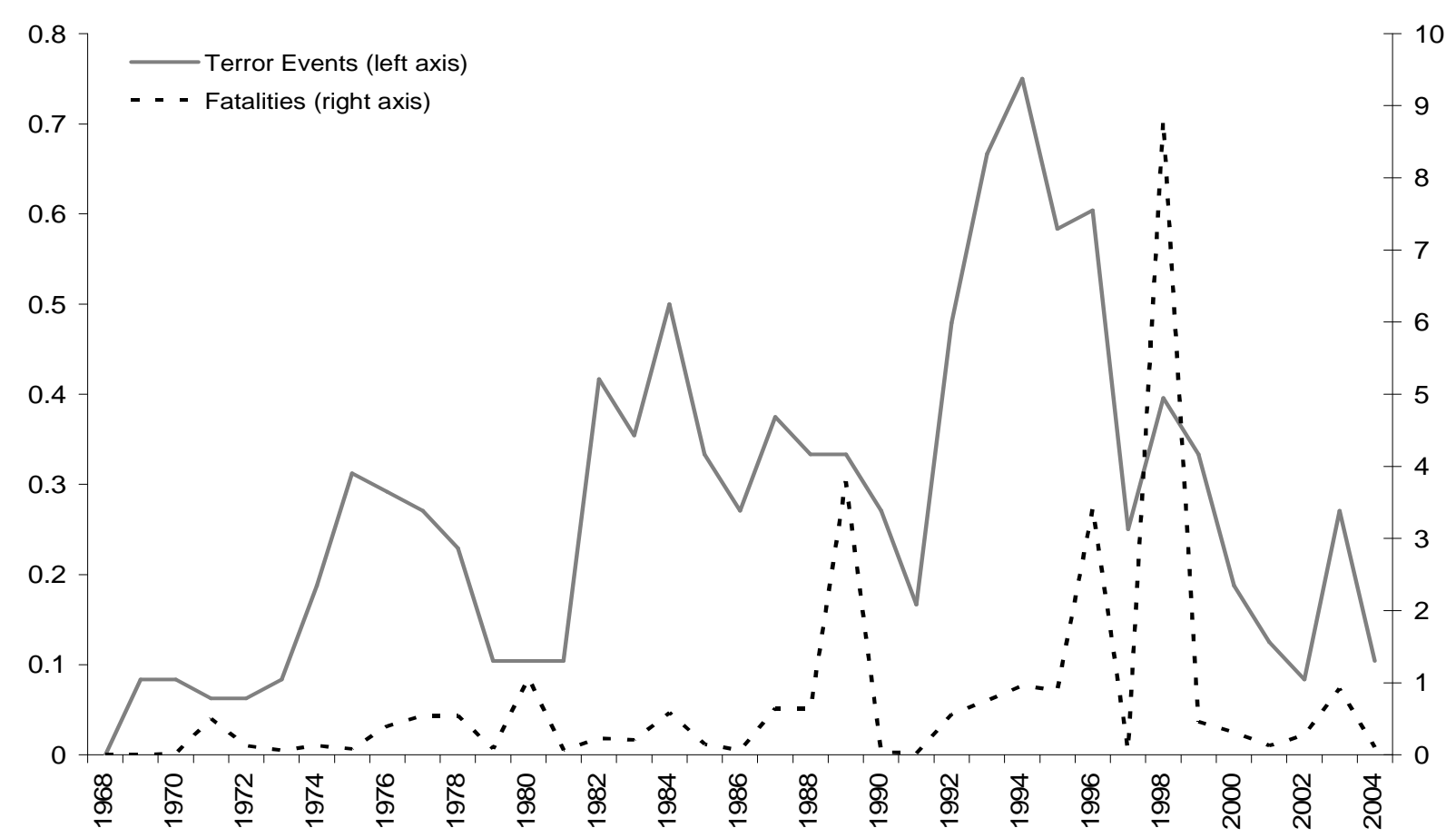

Figure 6.

Rolling Regression Results for Guerilla Warfare - Dependent variable: Terror Fatalities

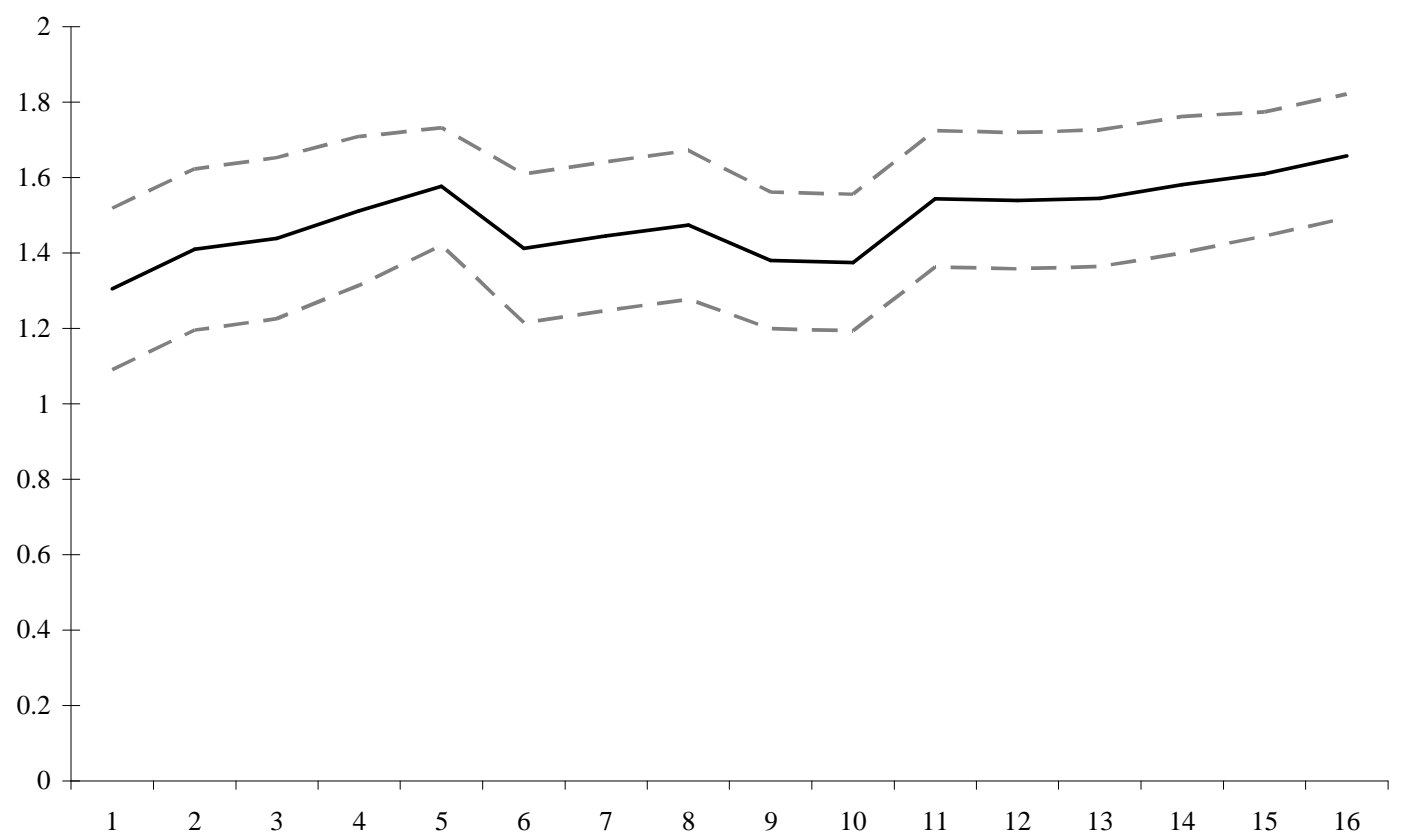

Note: This figure shows the outcome of rolling regressions of the specification presented in Table 5, column 1 . The dependent variable is terror fatalities and the rolling windows are for 15 years. Hence the first regression covers 1973-1987 and the last regression 1989-2003. It depicts the incidence-rate ratio and the $90 \%$-confidence interval. 


\begin{tabular}{|c|c|c|c|c|c|}
\hline \multicolumn{6}{|c|}{$\begin{array}{c}\text { Table } 1 . \\
\text { What do we Know About The Causes of International Terrorism? } \\
\text { An Overview of the Cross-Country Econometric Evidence }\end{array}$} \\
\hline STUDY & $\begin{array}{l}\text { Max No. of countries } \\
\text { Estimation (main) } \\
\text { Panel or cross-section }\end{array}$ & Terror measure & $\begin{array}{c}\text { Main } \\
\text { determinants }\end{array}$ & $\begin{array}{l}\text { Variables found not } \\
\text { significant }\end{array}$ & $\begin{array}{c}\text { Domestic } \\
\text { Political } \\
\text { Instability? }\end{array}$ \\
\hline $\begin{array}{c}\text { Weinberg and Eubank } \\
1998\end{array}$ & $175 \begin{array}{l}\text { Chi-square test } \\
\text { Cross-section }\end{array}$ & No. attacks & $\begin{array}{l}\text { Democracy; Transition to } \\
\text { and away from democracy }\end{array}$ & None & No \\
\hline $\begin{array}{c}\text { Eubank and Weinberg } \\
2001\end{array}$ & $175 \begin{array}{l}\text { Chi-square test } \\
\text { Cross-section }\end{array}$ & No. attacks & Stable Democracy & None & No \\
\hline $\begin{array}{c}\text { Krueger and Maleckova } \\
2003\end{array}$ & $\begin{array}{ll}148 & \text { Negative binomial } \\
\text { Cross-section }\end{array}$ & No. attacks & $\begin{array}{l}\text { Population (country size); } \\
\text { civil liberties }\end{array}$ & $\begin{array}{l}\text { GDP per capita; } \\
\text { Illiteracy }\end{array}$ & No \\
\hline $\begin{array}{c}\text { Blomberg et al. } \\
2004\end{array}$ & $\begin{array}{l}\text { ML Markov } \\
\text { Panel }\end{array}$ & No. attacks & $\begin{array}{c}\text { Democracy; GDP per } \\
\text { capita; GDP contractions }\end{array}$ & None & No \\
\hline $\begin{array}{l}\text { Li and Schaub } \\
2004\end{array}$ & $\begin{array}{c}112 \text { Negative binomial } \\
\text { Panel }\end{array}$ & No. attacks & $\begin{array}{l}\text { GDP per capita; Trade } \\
\text { partners' GDP per capita }\end{array}$ & $\begin{array}{l}\text { Trade; FDI; Interstate } \\
\text { conflict }\end{array}$ & No \\
\hline $\begin{array}{c}\text { Tavares } \\
2004\end{array}$ & $\begin{array}{c}\text { not reported } \\
\text { Panel }\end{array}$ & $\begin{array}{l}\text { No. attacks per } \\
\text { capita }\end{array}$ & $\begin{array}{l}\text { GDP , growth, diversity, } \\
\text { illiteracy; \% urban }\end{array}$ & $\begin{array}{c}\text { Political rights; primary } \\
\text { exporter; religious diversity }\end{array}$ & No \\
\hline $\begin{array}{c}L i \\
2005\end{array}$ & $\begin{array}{c}\text { Negative binomial } \\
\text { Panel }\end{array}$ & No. attacks & $\begin{array}{l}\text { Democracy; Gov } \\
\text { capability; regime durable }\end{array}$ & $\begin{array}{l}\text { Press freedom; Interstate } \\
\text { conflict; Gini; GDP }\end{array}$ & $\begin{array}{l}\text { Yes (regime } \\
\text { durability) }\end{array}$ \\
\hline $\begin{array}{l}\text { Goldstein } \\
2005\end{array}$ & $169 \begin{array}{cc}\text { OLS } \\
\text { Cross-section }\end{array}$ & $\begin{array}{l}\text { WMRC Global } \\
\text { Terrorism Index }\end{array}$ & $\begin{array}{l}\text { (Nonlinear) Pol Rights; ling } \\
\text { diversity; unemployment }\end{array}$ & GDP per capita; Gini; HDI & No \\
\hline $\begin{array}{l}\text { Abadie } \\
2006\end{array}$ & $156 \begin{array}{r}\text { OLS and IV } \\
\text { Cross-section }\end{array}$ & $\begin{array}{l}\text { WMRC Global } \\
\text { Terrorism Index }\end{array}$ & $\begin{array}{c}\text { (Nonlinear) Pol Rights; ling } \\
\text { diversity; geography }\end{array}$ & GDP per capita; Gini; HDI & No \\
\hline $\begin{array}{l}\text { Azam and Delacroix } \\
2006\end{array}$ & $\begin{array}{l}178 \text { Negative Binomial } \\
\text { Cross-section }\end{array}$ & No. attacks & $\begin{array}{c}\text { Aid; Population } \\
\text { (nonlinear); GDP per capita }\end{array}$ & None & No \\
\hline $\begin{array}{l}\text { Blomberg and Rosendorff } \\
2006\end{array}$ & $\begin{array}{l}\text { Tobit } \\
\text { Panel }\end{array}$ & No. attacks & $\begin{array}{c}\text { Democracy; GDP per } \\
\text { capita; Openness; Distance }\end{array}$ & IMF and WTO membership & No \\
\hline $\begin{array}{c}\text { Bravo and Dias } \\
2006\end{array}$ & 85 OLS & No. attacks & $\begin{array}{l}\text { Democracy; natural } \\
\text { resources; illiteracy }\end{array}$ & $\begin{array}{l}\text { Muslim population; trade } \\
\text { openness }\end{array}$ & No \\
\hline
\end{tabular}




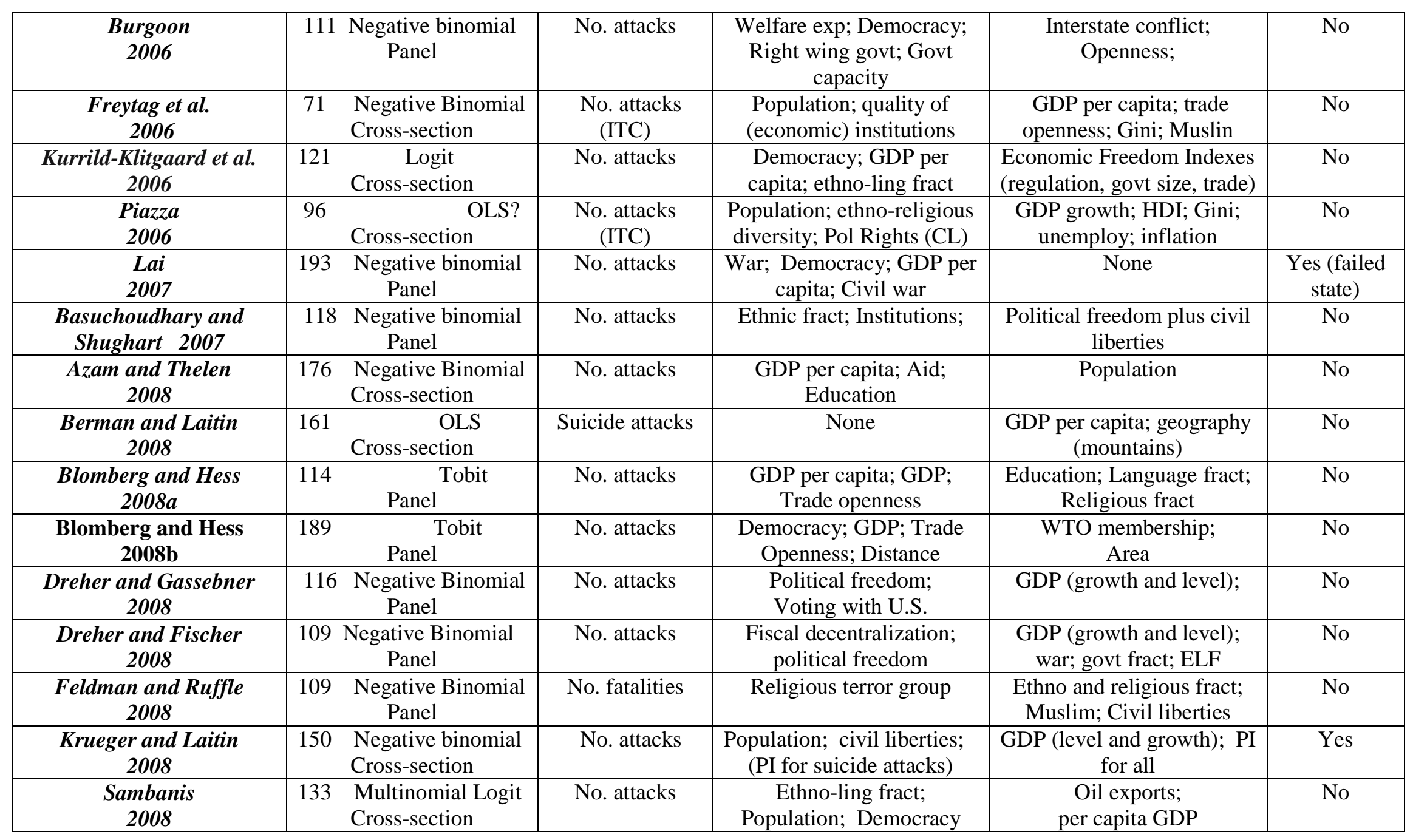


Table 2: Summary Statistics and Sources

\begin{tabular}{llrrrr}
\hline Variable & Source & Mean & Std. Dev. & Min & Max \\
\hline Terror Events & MIPT & 2.18 & 6.21 & 0 & 151 \\
Terror Fatalities & MIPT & 3.12 & 53.16 & 0 & 2982 \\
Median Fatalities & MIPT & 0.62 & 8.25 & 0 & 291 \\
Political Freedom & Freedom House (2005) & 3.80 & 1.96 & -7 & -1 \\
Political Freedom, change & Freedom House (2005) & 0.03 & 0.47 & -4.5 & 4 \\
GDP p.c. & World Bank (2006) & 5599.6 & 8132.2 & 56.52 & 50621 \\
Population & World Bank (2006) & $4.1 \mathrm{E}+07$ & $1.3 \mathrm{E}+08$ & 360849 & $1.3 \mathrm{E}+09$ \\
Regime duration & Maeshall and Jaggers (2002) & 23.73 & 30.26 & 0 & 193 \\
Civil War & Gleditsch et al. (2002) & 0.06 & 0.23 & 0 & 1 \\
Strikes & Databanks International (2005) & 0.18 & 0.60 & 0 & 7 \\
Guerilla Warfare & Databanks International (2005) & 0.16 & 0.42 & 0 & 3 \\
Riots & Databanks International (2005) & 0.46 & 1.70 & 0 & 26 \\
Demonstrations & Databanks International (2005) & 0.69 & 1.80 & 0 & 26 \\
Political proximity to U.S. Voeten (2004) & 0.29 & 0.14 & 0.06 & 0.84 \\
GDP growth p.c & World Bank (2006) & 1.39 & 6.11 & -50.5 & 89.8 \\
Aid & World Bank (2006) & 4.64 & 7.68 & -0.7 & 98.5 \\
OECD dummy & OECD webpage & 0.21 & 0.41 & 0 & 1 \\
Urbanization & World Bank (2006) & 50.88 & 23.93 & 2.9 & 100.0 \\
Openness & World Bank (2006) & 67.71 & 36.85 & 6.3 & 398.8 \\
\hline
\end{tabular}

Notes: The summary statistics were calculated base on the estimation sample of Table 3 column 1, with a maximum of 3447 observations. 
Table 3: Determinants of International Terror Events (Absolute Number), Developing and Developed Countries, 1972-2003, Fixed-Effects Negative Binomial Panel Estimates

\begin{tabular}{|c|c|c|c|c|c|c|c|c|}
\hline & (1) & (2) & (3) & (4) & $(5)$ & (6) & (7) & (8) \\
\hline Political Freedom, t-1 & $\begin{array}{c}1.1042 \\
(3.82)^{* * * *}\end{array}$ & $\begin{array}{l}1.0450 \\
(1.47)\end{array}$ & $\begin{array}{c}1.1090 \\
(3.96)^{* * *}\end{array}$ & $\begin{array}{c}1.0709 \\
(2.56)^{* *}\end{array}$ & $\begin{array}{c}1.1054 \\
(3.69)^{* * *}\end{array}$ & $\begin{array}{c}1.0814 \\
(2.97)^{* * *}\end{array}$ & $\begin{array}{c}1.1207 \\
(4.27)^{* * *}\end{array}$ & $\begin{array}{l}1.0285 \\
(0.88)\end{array}$ \\
\hline Political Freedom, change & $\begin{array}{c}0.9831 \\
(0.32)\end{array}$ & $\begin{array}{c}0.9797 \\
(0.36)\end{array}$ & $\begin{array}{c}0.9903 \\
(0.18)\end{array}$ & $\begin{array}{c}0.9633 \\
(0.70)\end{array}$ & $\begin{array}{c}0.9677 \\
(0.60)\end{array}$ & $\begin{array}{c}0.9707 \\
(0.56)\end{array}$ & $\begin{array}{c}0.9752 \\
(0.46)\end{array}$ & $\begin{array}{c}0.9410 \\
(1.03)\end{array}$ \\
\hline GDP p.c., t-1 & $\begin{array}{l}1.0000 \\
(1.56)\end{array}$ & $\begin{array}{l}1.0000 \\
(1.01)\end{array}$ & $\begin{array}{l}1.0000 \\
(1.60)\end{array}$ & $\begin{array}{l}1.0000 \\
(0.36)\end{array}$ & $\begin{array}{l}1.0000 \\
(1.53)\end{array}$ & $\begin{array}{l}1.0000 \\
(0.41)\end{array}$ & $\begin{array}{l}1.0000 \\
(1.29)\end{array}$ & $\begin{array}{l}1.0000 \\
(0.97)\end{array}$ \\
\hline Population, $\mathrm{t}-1$ & $\begin{array}{c}1.0000 \\
(2.46)^{* *}\end{array}$ & $\begin{array}{c}1.0000 \\
(2.45)^{* *}\end{array}$ & $\begin{array}{c}1.0000 \\
(2.73)^{* * *}\end{array}$ & $\begin{array}{c}1.0000 \\
(2.10)^{* *}\end{array}$ & $\begin{array}{c}1.0000 \\
(2.48)^{* *}\end{array}$ & $\begin{array}{c}1.0000 \\
(2.77)^{* * * *}\end{array}$ & $\begin{array}{c}1.0000 \\
(2.55)^{* *}\end{array}$ & $\begin{array}{c}1.0000 \\
(2.43)^{* *}\end{array}$ \\
\hline Regime duration, $\mathrm{t}-1$ & $\begin{array}{c}0.9938 \\
(3.67)^{* * *}\end{array}$ & $\begin{array}{c}0.9909 \\
(3.47)^{* * *}\end{array}$ & $\begin{array}{c}0.9934 \\
(3.85)^{* * *}\end{array}$ & $\begin{array}{c}0.9939 \\
(3.61)^{* * *}\end{array}$ & $\begin{array}{c}0.9940 \\
(3.34) * * *\end{array}$ & $\begin{array}{c}0.9940 \\
(3.55)^{* * * *}\end{array}$ & $\begin{array}{c}0.9941 \\
(3.39)^{* * *}\end{array}$ & $\begin{array}{c}0.9919 \\
(2.54)^{* *}\end{array}$ \\
\hline Civil War, t-1 & $\begin{array}{c}1.3042 \\
(2.80)^{* * *}\end{array}$ & $\begin{array}{c}1.2653 \\
(2.40)^{* *}\end{array}$ & $\begin{array}{c}1.3207 \\
(2.90)^{* * *}\end{array}$ & $\begin{array}{c}1.3275 \\
(2.98)^{* * *}\end{array}$ & $\begin{array}{c}1.3170 \\
(2.84)^{* * *}\end{array}$ & $\begin{array}{c}1.3395 \\
(3.07)^{* * *}\end{array}$ & $\begin{array}{c}1.3371 \\
(3.02)^{* * *}\end{array}$ & $\begin{array}{c}1.3387 \\
(2.85)^{* * *}\end{array}$ \\
\hline Strikes, $\mathrm{t}-1$ & $\begin{array}{c}0.9785 \\
(0.64)\end{array}$ & $\begin{array}{c}0.9688 \\
(0.82)\end{array}$ & $\begin{array}{c}0.9907 \\
(0.27)\end{array}$ & $\begin{array}{c}0.9864 \\
(0.40)\end{array}$ & $\begin{array}{c}0.9776 \\
(0.64)\end{array}$ & $\begin{array}{c}0.9671 \\
(0.98)\end{array}$ & $\begin{array}{c}0.9805 \\
(0.58)\end{array}$ & $\begin{array}{c}0.9641 \\
(0.90)\end{array}$ \\
\hline Guerilla Warfare, t-1 & $\begin{array}{c}1.3109 \\
(5.16)^{* * *}\end{array}$ & $\begin{array}{c}1.3136 \\
(4.78) * * *\end{array}$ & $\begin{array}{c}1.3049 \\
(5.05)^{* * *}\end{array}$ & $\begin{array}{c}1.2584 \\
(4.29)^{* * *}\end{array}$ & $\begin{array}{c}1.2947 \\
(4.85) * * *\end{array}$ & $\begin{array}{c}1.3098 \\
(5.19)^{* * *}\end{array}$ & $\begin{array}{c}1.2975 \\
(4.90)^{* * *}\end{array}$ & $\begin{array}{c}1.2705 \\
(4.05)^{* * *}\end{array}$ \\
\hline Riots, $\mathrm{t}-1$ & $\begin{array}{c}1.0344 \\
(2.77)^{* * *}\end{array}$ & $\begin{array}{c}1.0462 \\
(2.97)^{* * *}\end{array}$ & $\begin{array}{c}1.0342 \\
(2.79)^{* * * *}\end{array}$ & $\begin{array}{c}1.0328 \\
(2.66)^{* * *}\end{array}$ & $\begin{array}{c}1.0371 \\
(3.00)^{* * *}\end{array}$ & $\begin{array}{c}1.0343 \\
(2.80)^{* * *}\end{array}$ & $\begin{array}{c}1.0339 \\
(2.71)^{* * *}\end{array}$ & $\begin{array}{c}1.0484 \\
(3.11)^{* * *}\end{array}$ \\
\hline Demonstrations, $\mathrm{t}-1$ & $\begin{array}{l}1.0198 \\
(1.42)\end{array}$ & $\begin{array}{c}0.9852 \\
(0.88)\end{array}$ & $\begin{array}{l}1.0229 \\
(1.65)^{*}\end{array}$ & $\begin{array}{l}1.0220 \\
(1.59)\end{array}$ & $\begin{array}{c}1.0304 \\
(2.16)^{* *}\end{array}$ & $\begin{array}{l}1.0177 \\
(1.27)\end{array}$ & $\begin{array}{l}1.0219 \\
(1.57)\end{array}$ & $\begin{array}{c}0.9984 \\
(0.09)\end{array}$ \\
\hline Political proximity to U.S. & & $\begin{array}{c}3.2887 \\
(2.76) * * *\end{array}$ & & & & & & $\begin{array}{l}2.1688 \\
(1.65)^{*}\end{array}$ \\
\hline GDP growth p.c , t-1 & & & $\begin{array}{l}1.0037 \\
(0.83)\end{array}$ & & & & & $\begin{array}{l}1.0022 \\
(0.46)\end{array}$ \\
\hline OECD dummy, t-1 & & & & $\begin{array}{c}1.8189 \\
(4.14)^{* * * *}\end{array}$ & & & & $\begin{array}{c}1.4823 \\
(2.41)^{* *}\end{array}$ \\
\hline Aid, t-1 & & & & & $\begin{array}{l}1.0020 \\
(0.38)\end{array}$ & & & $\begin{array}{l}1.0037 \\
(0.65)\end{array}$ \\
\hline Urbanization, $\mathrm{t}-1$ & & & & & & $\begin{array}{c}1.0102 \\
(3.48)^{* * *}\end{array}$ & & $\begin{array}{c}1.0097 \\
(2.84)^{* * * *}\end{array}$ \\
\hline Openness, $\mathrm{t}-1$ & & & & & & & $\begin{array}{l}1.0013 \\
(0.90)\end{array}$ & $\begin{array}{l}1.0013 \\
(0.81)\end{array}$ \\
\hline Observations & 3447 & 3033 & 3419 & 3447 & 3321 & 3447 & 3315 & 2822 \\
\hline Countries & 132 & 122 & 132 & 132 & 130 & 132 & 128 & 119 \\
\hline
\end{tabular}

Notes: The results are based on conditional fixed effect negative binomial. All specifications include annual year dummies. The coefficients given in the table are incidence-rate ratios, i.e., values greater than 1 indicate an expected increase in terror events due to an increase in the respective variable while values smaller than 1 indicate a reduction.

$* / * * / * * *$ indicate significance at the $10 / 5 / 1-1 \%$ level; absolute value of $\mathrm{z}$-statistic is given in parentheses. 
Table 4: Determinants of International Terror Events (Absolute Number), By Region and Income Groups, 1972-2003, Fixed-Effects Negative Binomial Panel Estimates

\begin{tabular}{|c|c|c|c|c|c|c|c|c|c|}
\hline Region / Incc & $\begin{array}{c}\text { Asia } \\
(1)\end{array}$ & $\begin{array}{c}\text { Europe } \\
\text { (2) }\end{array}$ & $\begin{array}{c}\text { Americas } \\
\text { (3) }\end{array}$ & $\begin{array}{c}\text { Middle East } \\
\text { (4) }\end{array}$ & $\begin{array}{c}\text { Africa } \\
(5)\end{array}$ & $\begin{array}{c}\text { low } \\
(6)\end{array}$ & $\begin{array}{c}\text { lwr middle } \\
(7)\end{array}$ & $\begin{array}{c}\text { upr middle } \\
\text { (8) }\end{array}$ & $\begin{array}{l}\text { high } \\
(9)\end{array}$ \\
\hline Political Freedom, t-1 & $\begin{array}{l}1.0735 \\
(0.72)\end{array}$ & $\begin{array}{c}0.9370 \\
(0.73)\end{array}$ & $\begin{array}{l}1.0933 \\
(1.57)\end{array}$ & $\begin{array}{c}1.3445 \\
(2.42)^{* *}\end{array}$ & $\begin{array}{c}0.8168 \\
(1.64)\end{array}$ & $\begin{array}{l}0.8716 \\
(1.72)^{*}\end{array}$ & $\begin{array}{l}1.0605 \\
(1.04)\end{array}$ & $\begin{array}{c}1.1723 \\
(2.40) * *\end{array}$ & $\begin{array}{c}0.9971 \\
(0.04)\end{array}$ \\
\hline Political Freedom, change & $\begin{array}{l}1.0069 \\
(0.05)\end{array}$ & $\begin{array}{c}0.6629 \\
(2.33)^{* *}\end{array}$ & $\begin{array}{l}1.0421 \\
(0.47)\end{array}$ & $\begin{array}{l}1.3574 \\
(1.66)^{*}\end{array}$ & $\begin{array}{c}0.9497 \\
(0.29)\end{array}$ & $\begin{array}{l}1.0099 \\
(0.09)\end{array}$ & $\begin{array}{l}0.8343 \\
(1.87)^{*}\end{array}$ & $\begin{array}{l}1.1445 \\
(1.23)\end{array}$ & $\begin{array}{c}0.8484 \\
(0.97)\end{array}$ \\
\hline GDP p.c., t-1 & $\begin{array}{c}0.9999 \\
(1.41)\end{array}$ & $\begin{array}{l}1.0001 \\
(1.51)\end{array}$ & $\begin{array}{c}0.9999 \\
(1.39)\end{array}$ & $\begin{array}{c}1.0000 \\
(0.75)\end{array}$ & $\begin{array}{l}1.0006 \\
(1.25)\end{array}$ & $\begin{array}{c}1.0023 \\
(3.88)^{* * *}\end{array}$ & $\begin{array}{c}0.9998 \\
-0.94\end{array}$ & $\begin{array}{c}0.9998 \\
(3.77) * * *\end{array}$ & $\begin{array}{c}1.0000 \\
-1.6\end{array}$ \\
\hline Population, $\mathrm{t}-1$ & $\begin{array}{l}1.0000 \\
(1.45)\end{array}$ & $\begin{array}{l}1.0000 \\
(1.04)\end{array}$ & $\begin{array}{l}1.0000 \\
(0.27)\end{array}$ & $\begin{array}{l}1.0000 \\
(0.90)\end{array}$ & $\begin{array}{c}1.0000 \\
(4.26)^{* * * *}\end{array}$ & $\begin{array}{c}1.0000 \\
(4.58)^{* * *}\end{array}$ & $\begin{array}{c}1.0000 \\
(2.93)^{* * *}\end{array}$ & $\begin{array}{l}1.0000 \\
(0.12)\end{array}$ & $\begin{array}{l}1.0000 \\
(1.66)^{*}\end{array}$ \\
\hline Regime duration, $\mathrm{t}-1$ & $\begin{array}{c}0.9621 \\
(3.32)^{* * *}\end{array}$ & $\begin{array}{c}0.9814 \\
(1.98)^{* *}\end{array}$ & $\begin{array}{l}1.0081 \\
(1.34)\end{array}$ & $\begin{array}{c}1.0076 \\
(0.91)\end{array}$ & $\begin{array}{c}0.9436 \\
(3.70) * * *\end{array}$ & $\begin{array}{c}0.9385 \\
(6.30)^{* * *}\end{array}$ & $\begin{array}{c}0.9961 \\
(0.68)\end{array}$ & $\begin{array}{c}1.0325 \\
(4.49) * * *\end{array}$ & $\begin{array}{l}0.9940 \\
(1.73)^{*}\end{array}$ \\
\hline Civil War, $\mathrm{t}-1$ & $\begin{array}{c}1.8410 \\
(2.77)^{* * *}\end{array}$ & $\begin{array}{l}1.2774 \\
(0.92)\end{array}$ & $\begin{array}{l}1.1790 \\
(0.99)\end{array}$ & $\begin{array}{l}1.8484 \\
(1.69)^{*}\end{array}$ & $\begin{array}{l}1.5793 \\
(1.58)\end{array}$ & $\begin{array}{c}1.5124 \\
(2.06)^{* *}\end{array}$ & $\begin{array}{c}1.3617 \\
(2.29)^{* *}\end{array}$ & $\begin{array}{c}1.8897 \\
(1.89)^{*}\end{array}$ & \\
\hline Strikes, $\mathrm{t}-1$ & $\begin{array}{c}0.7897 \\
(2.27)^{* *}\end{array}$ & $\begin{array}{l}0.9411 \\
(0.63)\end{array}$ & $\begin{array}{l}1.0154 \\
(0.23)\end{array}$ & $\begin{array}{c}1.1030 \\
(1.00)\end{array}$ & $\begin{array}{c}0.8561 \\
(0.64)\end{array}$ & $\begin{array}{c}0.8703 \\
(1.41)\end{array}$ & $\begin{array}{l}1.1345 \\
(1.83)^{*}\end{array}$ & $\begin{array}{c}0.7758 \\
(2.59) * * *\end{array}$ & $\begin{array}{c}1.0214 \\
(0.32)\end{array}$ \\
\hline Guerilla Warfare, $\mathrm{t}-1$ & $\begin{array}{c}0.9974 \\
(0.02)\end{array}$ & $\begin{array}{l}1.1885 \\
(1.13)\end{array}$ & $\begin{array}{c}1.5968 \\
(4.50)^{* * * *}\end{array}$ & $\begin{array}{c}1.6010 \\
(2.44)^{* *}\end{array}$ & $\begin{array}{l}1.0271 \\
(0.14)\end{array}$ & $\begin{array}{l}1.1129 \\
(1.04)\end{array}$ & $\begin{array}{c}1.5845 \\
(4.83)^{* * *}\end{array}$ & $\begin{array}{c}1.5191 \\
(2.96)^{* * *}\end{array}$ & $\begin{array}{c}0.9562 \\
(0.34)\end{array}$ \\
\hline Riots, t-1 & $\begin{array}{c}1.1043 \\
(3.89) * * *\end{array}$ & $\begin{array}{c}0.9808 \\
(0.64)\end{array}$ & $\begin{array}{l}1.0846 \\
(1.41)\end{array}$ & $\begin{array}{l}1.0252 \\
(0.46)\end{array}$ & $\begin{array}{c}1.2519 \\
(2.02)^{* *}\end{array}$ & $\begin{array}{c}1.1064 \\
(4.07)^{* * *}\end{array}$ & $\begin{array}{l}1.0600 \\
(1.84)^{*}\end{array}$ & $\begin{array}{c}1.1258 \\
(3.02)^{* * *}\end{array}$ & $\begin{array}{c}1.0055 \\
(0.27)\end{array}$ \\
\hline Demonstrations, $\mathrm{t}-1$ & $\begin{array}{c}0.9970 \\
(0.09)\end{array}$ & $\begin{array}{l}1.0425 \\
(1.11)\end{array}$ & $\begin{array}{l}1.0380 \\
(1.07)\end{array}$ & $\begin{array}{c}0.9146 \\
(1.64)\end{array}$ & $\begin{array}{c}0.8664 \\
(1.17)\end{array}$ & $\begin{array}{c}0.9718 \\
(0.94)\end{array}$ & $\begin{array}{l}0.9546 \\
(1.69)^{*}\end{array}$ & $\begin{array}{c}1.0753 \\
(2.38)^{* *}\end{array}$ & $\begin{array}{l}1.0408 \\
(1.80)^{*}\end{array}$ \\
\hline Political proximity to U.S. & $\begin{array}{c}0.2445 \\
(0.56)\end{array}$ & $\begin{array}{c}2.4269 \\
(0.80)\end{array}$ & $\begin{array}{c}0.0387 \\
(2.34)^{* *}\end{array}$ & & $\begin{array}{c}0.1625 \\
(0.82)\end{array}$ & $\begin{array}{c}0.8469 \\
(0.14)\end{array}$ & $\begin{array}{c}3.1390 \\
(1.02)\end{array}$ & & \\
\hline GDP growth p.c, $\mathrm{t}-1$ & $\begin{array}{l}1.0486 \\
(1.82)^{*}\end{array}$ & $\begin{array}{l}1.0080 \\
(0.99)\end{array}$ & $\begin{array}{c}1.0007 \\
(0.05)\end{array}$ & $\begin{array}{c}0.9918 \\
(0.83)\end{array}$ & $\begin{array}{l}1.0009 \\
(0.08)\end{array}$ & $\begin{array}{c}0.9950 \\
(0.50)\end{array}$ & $\begin{array}{l}1.0102 \\
(1.44)\end{array}$ & $\begin{array}{l}1.0053 \\
(0.64)\end{array}$ & $\begin{array}{c}1.0228 \\
(0.99)\end{array}$ \\
\hline OECD dummy, $\mathrm{t}-1$ & $\begin{array}{c}3.0138 \\
(1.27)\end{array}$ & $\begin{array}{c}0.3557 \\
(2.02)^{* *}\end{array}$ & $\begin{array}{c}0.4088 \\
(1.13)\end{array}$ & & & & & & \\
\hline Aid, t-1 & $\begin{array}{l}1.0198 \\
(0.42)\end{array}$ & $\begin{array}{l}1.0222 \\
(1.53)\end{array}$ & $\begin{array}{c}0.9939 \\
(0.44)\end{array}$ & $\begin{array}{c}1.0474 \\
(2.50)^{* *}\end{array}$ & $\begin{array}{l}1.0130 \\
(1.29)\end{array}$ & $\begin{array}{l}1.0037 \\
(0.45)\end{array}$ & $\begin{array}{c}1.0096 \\
(0.78)\end{array}$ & $\begin{array}{l}1.1421 \\
(1.72)^{*}\end{array}$ & \\
\hline Urbanization, $\mathrm{t}-1$ & $\begin{array}{c}1.0624 \\
(3.57) * * *\end{array}$ & $\begin{array}{l}1.0141 \\
(1.01)\end{array}$ & $\begin{array}{c}1.0092 \\
(0.93)\end{array}$ & & $\begin{array}{l}1.0408 \\
(1.76)^{*}\end{array}$ & $\begin{array}{c}0.9939 \\
(0.36)\end{array}$ & $\begin{array}{c}1.0231 \\
(2.40)^{* *}\end{array}$ & $\begin{array}{c}0.9991 \\
(0.07)\end{array}$ & $\begin{array}{c}1.0172 \\
(1.44)\end{array}$ \\
\hline Openness, t-1 & $\begin{array}{c}0.9900 \\
(1.49)\end{array}$ & $\begin{array}{c}0.9969 \\
(0.84)\end{array}$ & $\begin{array}{c}0.9969 \\
(0.75)\end{array}$ & & $\begin{array}{c}1.0007 \\
(0.13)\end{array}$ & $\begin{array}{l}1.0002 \\
(0.06)\end{array}$ & $\begin{array}{l}1.0062 \\
(1.84)^{*}\end{array}$ & $\begin{array}{l}0.9931 \\
(1.84)^{*}\end{array}$ & $\begin{array}{c}0.9924 \\
(1.55)\end{array}$ \\
\hline$\overline{\text { Observations }}$ & 453 & 593 & 622 & 388 & 785 & 1026 & 810 & 531 & 651 \\
\hline Countries & 18 & 34 & 21 & 15 & 31 & 43 & 37 & 22 & 21 \\
\hline
\end{tabular}

Notes: The results are based on conditional fixed effect negative binomial. All specifications include annual year dummies. The coefficients given in the table are incidence-rate ratios, i.e., values greater than 1 indicate an expected increase in terror events due to an increase in the respective variable while values smaller than 1 indicate a reduction. The region and income group classification is taken from Easterly and Sewadeh (2001). This table reports our attempts to fit the full specification from column 8 in Table 3 to various split samples. The variables for which no coefficients are reported (e.g., OECD dummy for the Middle East in column 4) were dropped in the estimation so as to allow the estimates to convergence.

$* / * * / * * *$ indicate significance at the 10/5/1-1\% level; absolute value of $\mathrm{z}$-statistic is given in parentheses. 
Table 5: Determinants of International Terror Events (Number of Fatalities), Developing and Developed Countries, 1972-2003, Fixed-Effects Negative Binomial Panel Estimates

\begin{tabular}{|c|c|c|c|c|c|c|c|c|}
\hline & (1) & (2) & (3) & (4) & $(5)$ & (6) & (7) & $(8)$ \\
\hline Political Freedom, t-1 & $\begin{array}{c}1.1391 \\
(3.83)^{* * *}\end{array}$ & $\begin{array}{c}1.0938 \\
(2.29)^{* *}\end{array}$ & $\begin{array}{c}1.1415 \\
(3.83)^{* * *}\end{array}$ & $\begin{array}{c}1.0825 \\
(2.12)^{* *}\end{array}$ & $\begin{array}{c}1.1356 \\
(3.62)^{* * *}\end{array}$ & $\begin{array}{l}1.0622 \\
(1.75)^{*}\end{array}$ & $\begin{array}{c}1.1381 \\
(3.72)^{* * *}\end{array}$ & $\begin{array}{c}0.9869 \\
(0.31)\end{array}$ \\
\hline Political Freedom, change & $\begin{array}{c}0.9321 \\
(0.82)\end{array}$ & $\begin{array}{c}0.9184 \\
(0.95)\end{array}$ & $\begin{array}{c}0.9528 \\
(0.56)\end{array}$ & $\begin{array}{c}0.9072 \\
(1.13)\end{array}$ & $\begin{array}{c}0.9256 \\
(0.89)\end{array}$ & $\begin{array}{c}0.8893 \\
(1.36)\end{array}$ & $\begin{array}{c}0.9196 \\
(0.97)\end{array}$ & $\begin{array}{c}0.8729 \\
(1.51)\end{array}$ \\
\hline GDP p.c., t-1 & $\begin{array}{c}1.0000 \\
(4.43)^{* * *}\end{array}$ & $\begin{array}{c}1.0000 \\
(3.04)^{* * *}\end{array}$ & $\begin{array}{c}1.0000 \\
(4.27)^{* * *}\end{array}$ & $\begin{array}{c}1.0000 \\
(2.84)^{* * *}\end{array}$ & $\begin{array}{c}1.0000 \\
(3.81)^{* * *}\end{array}$ & $\begin{array}{c}1.0000 \\
(0.56)\end{array}$ & $\begin{array}{c}1.0000 \\
(4.38)^{* * *}\end{array}$ & $\begin{array}{c}0.9999 \\
(2.05)^{* *}\end{array}$ \\
\hline Population, $\mathrm{t}-1$ & $\begin{array}{c}1.0000 \\
(0.31)\end{array}$ & $\begin{array}{l}1.0000 \\
(0.15)\end{array}$ & $\begin{array}{l}1.0000 \\
(0.35)\end{array}$ & $\begin{array}{c}1.0000 \\
(0.01)\end{array}$ & $\begin{array}{l}1.0000 \\
(0.88)\end{array}$ & $\begin{array}{l}1.0000 \\
(1.65)^{*}\end{array}$ & $\begin{array}{l}1.0000 \\
(0.62)\end{array}$ & $\begin{array}{l}1.0000 \\
(0.56)\end{array}$ \\
\hline luration, $\mathrm{t}-1$ & $\begin{array}{c}0.9900 \\
(5.33) * * *\end{array}$ & $\begin{array}{c}0.9873 \\
(3.48)^{* * *}\end{array}$ & $\begin{array}{c}0.9899 \\
(5.29)^{* * *}\end{array}$ & $\begin{array}{c}0.9890 \\
(5.74) * * *\end{array}$ & $\begin{array}{c}0.9905 \\
(4.85)^{* * *}\end{array}$ & $\begin{array}{c}0.9907 \\
(4.88)^{* * *}\end{array}$ & $\begin{array}{c}0.9898 \\
(5.32)^{* * *}\end{array}$ & $\begin{array}{c}0.9908 \\
(2.16)^{* *}\end{array}$ \\
\hline Civil War, t-1 & $\begin{array}{c}1.4741 \\
(2.83) * * *\end{array}$ & $\begin{array}{c}1.4818 \\
(2.80)^{* * *}\end{array}$ & $\begin{array}{c}1.4973 \\
(2.91)^{* * *}\end{array}$ & $\begin{array}{c}1.4727 \\
(2.83)^{* * *}\end{array}$ & $\begin{array}{c}1.4650 \\
(2.76) * * *\end{array}$ & $\begin{array}{c}1.6271 \\
(3.55)^{* * *}\end{array}$ & $\begin{array}{c}1.4451 \\
(2.64)^{* * *}\end{array}$ & $\begin{array}{c}1.5405 \\
(2.99) * * *\end{array}$ \\
\hline Strikes, $\mathrm{t}-1$ & $\begin{array}{l}1.0320 \\
(0.59)\end{array}$ & $\begin{array}{c}0.9606 \\
(0.68)\end{array}$ & $\begin{array}{l}1.0487 \\
(0.89)\end{array}$ & $\begin{array}{l}1.0503 \\
(0.92)\end{array}$ & $\begin{array}{c}1.0530 \\
(0.97)\end{array}$ & $\begin{array}{c}0.9778 \\
(0.42)\end{array}$ & $\begin{array}{l}1.0280 \\
(0.52)\end{array}$ & $\begin{array}{c}0.9471 \\
(0.89)\end{array}$ \\
\hline Guerilla Warfare, t-1 & $\begin{array}{c}1.5896 \\
(5.78)^{* * *}\end{array}$ & $\begin{array}{c}1.7267 \\
(6.34)^{* * *}\end{array}$ & $\begin{array}{c}1.5826 \\
(5.67)^{* * *}\end{array}$ & $\begin{array}{c}1.5658 \\
(5.59)^{* * *}\end{array}$ & $\begin{array}{c}1.5915 \\
(5.76)^{* * *}\end{array}$ & $\begin{array}{c}1.5807 \\
(5.84)^{* * *}\end{array}$ & $\begin{array}{c}1.5972 \\
(5.82)^{* * *}\end{array}$ & $\begin{array}{c}1.7408 \\
(6.50)^{* * * *}\end{array}$ \\
\hline Riots, t-1 & $\begin{array}{c}0.9945 \\
(0.27)\end{array}$ & $\begin{array}{l}1.0301 \\
(1.25)\end{array}$ & $\begin{array}{c}0.9933 \\
(0.34)\end{array}$ & $\begin{array}{c}0.9932 \\
(0.34)\end{array}$ & $\begin{array}{c}0.9951 \\
(0.24)\end{array}$ & $\begin{array}{l}1.0030 \\
(0.15)\end{array}$ & $\begin{array}{c}0.9936 \\
(0.31)\end{array}$ & $\begin{array}{l}1.0454 \\
(1.90)^{*}\end{array}$ \\
\hline Demo & $\begin{array}{c}1.0659 \\
(3.14)^{* * *}\end{array}$ & $\begin{array}{l}1.0309 \\
(1.17)\end{array}$ & $\begin{array}{c}1.0694 \\
(3.30)^{* * *}\end{array}$ & $\begin{array}{c}1.0698 \\
(3.34)^{* * *}\end{array}$ & $\begin{array}{c}1.0731 \\
(3.46)^{* * *}\end{array}$ & $\begin{array}{c}1.0459 \\
(2.18)^{* *}\end{array}$ & $\begin{array}{c}1.0660 \\
(3.12)^{* * *}\end{array}$ & $\begin{array}{l}1.0180 \\
(0.65)\end{array}$ \\
\hline Political proximity to U.S. & & $\begin{array}{c}11.0910 \\
(4.42)^{* * *}\end{array}$ & & & & & & $\begin{array}{c}10.2237 \\
(3.96)^{* * *}\end{array}$ \\
\hline GDP growth p.c , t-1 & & & $\begin{array}{l}1.0043 \\
(0.65)\end{array}$ & & & & & $\begin{array}{c}1.0042 \\
(0.60)\end{array}$ \\
\hline OECD dummy, t-1 & & & & $\begin{array}{c}1.8944 \\
(3.37)^{* * *}\end{array}$ & & & & $\begin{array}{c}1.7778 \\
(2.68)^{* * *}\end{array}$ \\
\hline Aid, $\mathrm{t}-1$ & & & & & $\begin{array}{c}0.9884 \\
(1.41)\end{array}$ & & & $\begin{array}{l}1.0002 \\
(0.02)\end{array}$ \\
\hline Urbanization, t-1 & & & & & & $\begin{array}{c}1.0255 \\
(7.73)^{* * *}\end{array}$ & & $\begin{array}{c}1.0284 \\
(7.16)^{* * *}\end{array}$ \\
\hline Openness, t-1 & & & & & & & $\begin{array}{c}0.9982 \\
(1.11)\end{array}$ & $\begin{array}{c}0.9972 \\
(1.51)\end{array}$ \\
\hline Obse & 2885 & 2502 & 2860 & 2885 & 274 & 2885 & 2787 & 2335 \\
\hline Countries & 107 & 97 & 107 & 107 & 103 & 107 & 104 & 94 \\
\hline
\end{tabular}

Notes: The results are based on conditional fixed effect negative binomial. All specifications include annual year dummies. The coefficients given in the table are incidence-rate ratios, i.e., values greater than 1 indicate an expected increase in terror fatalities due to an increase in the respective variable while values smaller than 1 indicate a reduction..

$* / * * / * * *$ indicate significance at the 10/5/1-1\% level; absolute value of $\mathrm{z}$-statistic is given in parentheses. 
Table 6: Determinants of International Terror Events (Median Severity International Terror Event), Developing and Developed Countries, 1972-2003, Fixed-Effects Negative Binomial Panel Estimates

\begin{tabular}{|c|c|c|c|c|c|c|c|c|}
\hline & (1) & (2) & (3) & (4) & $(5)$ & (6) & (7) & (8) \\
\hline Political Freedom, t-1 & $\begin{array}{l}1.0598 \\
(1.21)\end{array}$ & $\begin{array}{l}1.0261 \\
(0.47)\end{array}$ & $\begin{array}{l}1.0700 \\
(1.38)\end{array}$ & $\begin{array}{l}1.0608 \\
(1.11)\end{array}$ & $\begin{array}{l}1.0817 \\
(1.56)\end{array}$ & $\begin{array}{l}1.0234 \\
(0.48)\end{array}$ & $\begin{array}{l}1.0700 \\
(1.37)\end{array}$ & $\begin{array}{c}0.9836 \\
(0.26)\end{array}$ \\
\hline Political Freedom, change & $\begin{array}{c}0.8594 \\
(1.30)\end{array}$ & $\begin{array}{l}0.8357 \\
(1.50)\end{array}$ & $\begin{array}{c}0.8514 \\
(1.35)\end{array}$ & $\begin{array}{c}0.8598 \\
(1.29)\end{array}$ & $\begin{array}{c}0.8445 \\
(1.43)\end{array}$ & $\begin{array}{c}0.8376 \\
(1.49)\end{array}$ & $\begin{array}{c}0.8392 \\
(1.50)\end{array}$ & $\begin{array}{l}0.7875 \\
(1.91)^{*}\end{array}$ \\
\hline GDP p.c., t-1 & $\begin{array}{c}1.0000 \\
(2.45)^{* *}\end{array}$ & $\begin{array}{c}1.0001 \\
(2.75)^{* * *}\end{array}$ & $\begin{array}{l}1.0000 \\
(1.95)^{*}\end{array}$ & $\begin{array}{c}1.0000 \\
(2.36)^{* *}\end{array}$ & $\begin{array}{c}1.0000 \\
(2.45)^{* *}\end{array}$ & $\begin{array}{l}1.0000 \\
(0.49)\end{array}$ & $\begin{array}{c}1.0000 \\
(2.56)^{* *}\end{array}$ & $\begin{array}{c}0.9999 \\
(0.12)\end{array}$ \\
\hline Population, $\mathrm{t}-1$ & $\begin{array}{l}1.0000 \\
(1.37)\end{array}$ & $\begin{array}{c}1.0000 \\
(2.44)^{* *}\end{array}$ & $\begin{array}{l}1.0000 \\
(1.35)\end{array}$ & $\begin{array}{l}1.0000 \\
(1.36)\end{array}$ & $\begin{array}{l}1.0000 \\
(1.18)\end{array}$ & $\begin{array}{c}1.0000 \\
(2.33)^{* *}\end{array}$ & $\begin{array}{l}1.0000 \\
(1.10)\end{array}$ & $\begin{array}{c}1.0000 \\
(2.73)^{* * *}\end{array}$ \\
\hline Regime duration, t-1 & $\begin{array}{c}0.9863 \\
(4.06) * * *\end{array}$ & $\begin{array}{c}0.9814 \\
(3.47)^{* * *}\end{array}$ & $\begin{array}{c}0.9871 \\
(3.72)^{* * *}\end{array}$ & $\begin{array}{c}0.9863 \\
(3.65)^{* * *}\end{array}$ & $\begin{array}{c}0.9858 \\
(4.05)^{* * *}\end{array}$ & $\begin{array}{c}0.9849 \\
(4.35)^{* * *}\end{array}$ & $\begin{array}{c}0.9852 \\
(4.26)^{* * *}\end{array}$ & $\begin{array}{c}0.9740 \\
(4.12)^{* * *}\end{array}$ \\
\hline Civil War, t-1 & $\begin{array}{l}1.4144 \\
(1.79)^{*}\end{array}$ & $\begin{array}{c}1.5094 \\
(2.08)^{* *}\end{array}$ & $\begin{array}{l}1.3486 \\
(1.52)\end{array}$ & $\begin{array}{l}1.4149 \\
(1.79)^{*}\end{array}$ & $\begin{array}{l}1.4316 \\
(1.84)^{*}\end{array}$ & $\begin{array}{c}1.5221 \\
(2.15)^{* *}\end{array}$ & $\begin{array}{l}1.3365 \\
(1.46)\end{array}$ & $\begin{array}{l}1.4058 \\
(1.62)\end{array}$ \\
\hline Strikes, $\mathrm{t}-1$ & $\begin{array}{c}0.9961 \\
(0.04)\end{array}$ & $\begin{array}{c}0.9279 \\
(0.68)\end{array}$ & $\begin{array}{c}0.9935 \\
(0.06)\end{array}$ & $\begin{array}{c}0.9961 \\
(0.04)\end{array}$ & $\begin{array}{l}1.0141 \\
(0.14)\end{array}$ & $\begin{array}{c}0.9644 \\
(0.36)\end{array}$ & $\begin{array}{c}0.9850 \\
(0.15)\end{array}$ & $\begin{array}{c}0.9099 \\
(0.83)\end{array}$ \\
\hline Guerilla Warfare, t-1 & $\begin{array}{c}1.5821 \\
(3.81)^{* * *}\end{array}$ & $\begin{array}{c}1.5344 \\
(3.40)^{* * *}\end{array}$ & $\begin{array}{c}1.6063 \\
(3.91)^{* * *}\end{array}$ & $\begin{array}{c}1.5822 \\
(3.80)^{* * *}\end{array}$ & $\begin{array}{c}1.6176 \\
(3.97)^{* * *}\end{array}$ & $\begin{array}{c}1.5948 \\
(3.91)^{* * *}\end{array}$ & $\begin{array}{c}1.6201 \\
(4.01)^{* * *}\end{array}$ & $\begin{array}{c}1.5799 \\
(3.62)^{* * *}\end{array}$ \\
\hline Riots, t-1 & $\begin{array}{c}0.9563 \\
(1.23)\end{array}$ & $\begin{array}{c}0.9768 \\
(0.62)\end{array}$ & $\begin{array}{c}0.9572 \\
(1.22)\end{array}$ & $\begin{array}{c}0.9563 \\
(1.23)\end{array}$ & $\begin{array}{l}0.9515 \\
(1.35)\end{array}$ & $\begin{array}{c}0.9635 \\
(1.02)\end{array}$ & $\begin{array}{c}0.9571 \\
(1.21)\end{array}$ & $\begin{array}{c}0.9837 \\
(0.42)\end{array}$ \\
\hline Demonstrations, $\mathrm{t}-1$ & $\begin{array}{c}1.0859 \\
(2.42)^{* *}\end{array}$ & $\begin{array}{l}1.0606 \\
(1.48)\end{array}$ & $\begin{array}{c}1.0845 \\
(2.38)^{* *}\end{array}$ & $\begin{array}{c}1.0858 \\
(2.41)^{* *}\end{array}$ & $\begin{array}{c}1.0962 \\
(2.68) * * *\end{array}$ & $\begin{array}{c}1.0726 \\
(2.04)^{* *}\end{array}$ & $\begin{array}{c}1.0834 \\
(2.32)^{* *}\end{array}$ & $\begin{array}{l}1.0511 \\
(1.19)\end{array}$ \\
\hline Political proximity to U.S. & & $\begin{array}{c}28.0038 \\
(4.07)^{* * *}\end{array}$ & & & & & & $\begin{array}{c}49.8017 \\
(4.30)^{* * *}\end{array}$ \\
\hline GDP growth p.c, $\mathrm{t}-1$ & & & $\begin{array}{c}0.9936 \\
(0.70)\end{array}$ & & & & & $\begin{array}{c}0.9974 \\
(0.28)\end{array}$ \\
\hline OECD dummy, $\mathrm{t}-1$ & & & & $\begin{array}{c}0.9833 \\
(0.04)\end{array}$ & & & & $\begin{array}{c}2.0940 \\
(1.28)\end{array}$ \\
\hline Aid, $\mathrm{t}-1$ & & & & & $\begin{array}{l}1.0052 \\
(0.51)\end{array}$ & & & $\begin{array}{l}1.0062 \\
(0.57)\end{array}$ \\
\hline Urbanization, t-1 & & & & & & $\begin{array}{c}1.0228 \\
(4.40)^{* * *}\end{array}$ & & $\begin{array}{c}1.0309 \\
(4.85)^{* * *}\end{array}$ \\
\hline Openness, $\mathrm{t}-1$ & & & & & & & $\begin{array}{c}0.9976 \\
(1.03) \\
\end{array}$ & $\begin{array}{c}0.9918 \\
(2.94)^{* * *}\end{array}$ \\
\hline Obser & 2633 & 2289 & 2607 & 2633 & 2495 & 2633 & 2535 & 2123 \\
\hline Countries & 98 & 89 & 97 & 98 & 94 & 98 & 95 & 86 \\
\hline
\end{tabular}

Notes: The results are based on conditional fixed effect negative binomial. All specifications include annual year dummies. The coefficients given in the table are incidence-rate ratios, i.e., values greater than 1 indicate an expected increase in the number of fatalities at the median event due to an increase in the respective variable while values smaller than 1 indicate a reduction..

$* / * * / * * *$ indicate significance at the 10/5/1-1\% level; absolute value of z-statistic is given in parentheses. 